\title{
Bromine partitioning in the tropical tropopause layer: implications for stratospheric injection
}

\author{
R. P. Fernandez ${ }^{1}$, R. J. Salawitch ${ }^{2}$, D. E. Kinnison ${ }^{3}$, J.-F. Lamarque ${ }^{3}$, and A. Saiz-Lopez ${ }^{1}$ \\ ${ }^{1}$ Atmospheric Chemistry and Climate Group, Institute of Physical Chemistry Rocasolano, CSIC, Madrid 28006, Spain \\ ${ }^{2}$ Department of Atmospheric and Oceanic Science, Department of Chemistry and Biochemistry, and Earth System Science \\ Interdisciplinary Center, University of Maryland, College Park, Maryland, MD 20742, USA \\ ${ }^{3}$ Atmospheric Chemistry Division, NCAR, Boulder, CO 80301, USA \\ Correspondence to: A. Saiz-Lopez (a.saiz@csic.es)
}

Received: 29 May 2014 - Published in Atmos. Chem. Phys. Discuss.: 3 July 2014

Revised: 8 October 2014 - Accepted: 13 October 2014 - Published: 16 December 2014

\begin{abstract}
Very short-lived (VSL) bromocarbons are produced at a prodigious rate by ocean biology and these source compounds ( $\mathrm{SG}_{\mathrm{VSL}}$ ), together with their inorganic degradation products $\left(\mathrm{PG}_{\mathrm{VSL}}\right)$, are lofted by vigorous convection to the tropical tropopause layer (TTL). Using a state-of-the-art photochemical mechanism within a global model, we calculate annual average stratospheric injection of total bromine due to VSL sources to be 5 pptv (parts per trillion by volume), with $\sim 3$ pptv entering the stratosphere as PGVSL and $\sim 2$ pptv as $\mathrm{SG}_{\mathrm{VSL}}$. The geographic distribution and partitioning of VSL bromine within the TTL, and its consequent stratospheric injection, is highly dependent on the oceanic flux, the strength of convection and the occurrence of heterogeneous recycling reactions. Our calculations indicate atomic $\mathrm{Br}$ should be the dominant inorganic species in large regions of the TTL during daytime, due to the low ozone and cold conditions of this region. We propose the existence of a "tropical ring of atomic bromine" located approximately between 15 and $19 \mathrm{~km}$ and between $30^{\circ} \mathrm{N}$ and $30^{\circ} \mathrm{S}$. Daytime $\mathrm{Br} / \mathrm{BrO}$ ratios of up to $\sim 4$ are predicted within this inhomogeneous ring in regions of highly convective transport, such as the tropical Western Pacific. Therefore, we suggest that experimental programs designed to quantify the bromine budget of the TTL and the stratospheric injection of VSL biogenic bromocarbons should include a strategy for the measurement of atomic $\mathrm{Br}$ during daytime as well as $\mathrm{HOBr}$ and $\mathrm{BrCl}$ during nighttime.
\end{abstract}

\section{Introduction}

Bromine compounds produced by biogenic processes in the oceans may influence the composition of the global atmosphere via their decomposition and the subsequent influence of the resulting bromine radicals on the tropospheric and stratospheric ozone budget, oxidation of elemental mercury and dimethyl sulfide (DMS) (Saiz-Lopez and von Glasow, 2012). Contributions of these biogenic sources, commonly known as very short-lived (VSL) bromocarbons, to inorganic bromine $\left(\mathrm{Br}_{\mathrm{y}}\right)$ in the stratosphere (Ko et al., 1997; Pfeilsticker et al., 2000; Salawitch et al., 2005; Salawitch, 2006) would have important climatic effects on ozone photochemistry and trends (Dorf et al., 2006; Sinnhuber et al., 2009), and have been proposed as the missing contribution required to reconcile measurements and model simulations of stratospheric bromine chemistry (Montzka et al., 2011).

Considerable effort is presently being extended towards quantifying the oceanic production (Carpenter and Liss, 2000; Quack and Wallace, 2003; Pyle et al., 2011; Leedham et al., 2013; Liu et al., 2013) and convective transport (Ashfold et al., 2012; Fuhlbrügge et al., 2013) of biogenic VSL bromocarbons, as well as understanding the chemical transformations of these compounds to inorganic bromine species in the atmosphere (Yang et al., 2005; Salawitch, 2006; Hossaini et al., 2010; Parrella et al., 2012; Saiz-Lopez et al., 2012; Sommariva and von Glasow, 2012; Aschmann and Sinnhuber, 2013; Liang et al., 2014). Several global halocarbon emission inventories have been developed (Warwick et al., 2006; Liang et al., 2010; Ordóñez et al., 2012; Ziska et 
al., 2013) and compared (Hossaini et al., 2013) to address the contribution of VSL bromocarbons to the photochemistry of the troposphere and the stratospheric bromine injection. The short photochemical lifetime of many biogenic VSL bromocarbons (i.e., weeks to months, see Table 1) results in photochemical breakdown and release of reactive bromine atoms in the troposphere (Montzka et al., 2011), mainly in the tropical tropopause layer (TTL). The quantification of brominated organic source gas (SG) and inorganic product gas (PG) distributions in the TTL is of great importance for determining the impact of the VSL bromocarbons on the ozone budget of the free troposphere and lowermost stratosphere (Salawitch et al., 2005; Montzka et al., 2011; Aschmann and Sinnhuber, 2013; Liang et al., 2014).

While many global model simulations indicate that the SG injection or carbon-bonded portion $\left(\mathrm{SG}_{\mathrm{VSL}}\right)$ is the dominant contribution of VSL bromocarbons to stratospheric bromine loading (Aschmann et al., 2009; Hossaini et al., 2010, 2012; Aschmann and Sinnhuber, 2013), the combination of heterogeneous recycling processes and rapid gaseous cycling of the inorganic PG species ( $\mathrm{PG}_{\mathrm{VSL}}$, also referred hereafter as $\mathrm{Br}_{\mathrm{y}}$ ) increases the lifetime of tropospheric bromine against washout by shifting the balance to the more hydrophilic inorganic portion (Parrella et al., 2012; Aschmann and Sinnhuber, 2013). Hence, the amount of inorganic bromine injected into the stratosphere is critically dependent on the balance between the efficiency of $\mathrm{Br}_{\mathrm{y}}$ removal by aerosol, water and ice-uptake (followed by particle sedimentation) and the heterogeneous recycling reactions that produce photolabile $\mathrm{PG}_{\mathrm{VSL}}$ species back to the gaseous phase (Sinnhuber and Folkins, 2006; Liang et al., 2010; Aschmann et al., 2011; Ordóñez et al., 2012; Aschmann and Sinnhuber, 2013). Additionally, the local convection would directly affect the timescale of the vertical transport (Aschmann et al., 2009; Hossaini et al., 2010; Ashfold et al., 2012; Liang et al., 2014), which also influences the $\mathrm{SG}_{V S L}$ and $\mathrm{PG}_{\mathrm{VSL}}$ lifetimes.

Experimental campaigns are underway to measure the abundance and speciation of a host of organic bromine species and the dominant inorganic compounds within the TTL (Dorf et al., 2008; Brinckmann et al., 2012; Wisher et al., 2014; ATTREX, 2014; CAST, 2014; CONTRAST, 2014), because this region is critical for quantifying the fate of biogenic bromine decomposition products and their impact on atmospheric chemistry (Hossaini et al., 2012; SaizLopez et al., 2012; Aschmann and Sinnhuber, 2013; Liang et al., 2014). Here we highlight some of the unique aspects of the TTL that drive the partitioning of inorganic bromine species by means of combined global- and box-modeling simulations. Based on our results, we discuss implications for the understanding of inorganic bromine chemistry and transport within the TTL, and assess its relevance on estimations of stratospheric bromine injection from VSL bromocarbon sources.

\subsection{The tropical tropopause layer}

The tropopause transition layer or tropical tropopause layer is the region between the lapse rate minimum at $\sim 12 \mathrm{~km}$ (i.e., with a zero radiative heating potential temperature $\left.\theta_{\mathrm{ZRH}} \approx 350 \mathrm{~K}\right)$ and the cold point tropopause $\left(\theta_{\mathrm{CPT}} \approx 380 \mathrm{~K}\right.$, at $\sim 17 \mathrm{~km}$; see Gettelman and Forster, 2002). The TTL definition used here has been taken from the $2010 \mathrm{WMO} / \mathrm{UNEP}$ (World Meteorological Organization/United Nations Environment Programme) report (Montzka et al., 2011). Differences on the upper and lower TTL limits with respect to other studies (Fueglistaler et al., 2009; Randel and Jensen, 2013) has no bearing on the scientific results of this study. Most gases that enter the stratosphere are first transported upwards by deep convection that detrains within the TTL (Sinnhuber and Folkins, 2006), followed by large-scale ascent.

Chemically, the TTL is characterized by low ozone and cold conditions. Very low ozone mixing ratios between 25 and $50 \mathrm{ppbv}$ (parts per billion by volume) are routinely observed for vast regions of the TTL (Thompson et al., 2003), usually in the lower TTL. Folkins and Braun (2002) noted that air parcels in the TTL with ozone mixing ratios $<25$ ppbv are "likely to be of recent boundary layer origin", and they used low ozone as a proxy for recent, deep convection. Murphy et al. (1993) showed profiles of $\mathrm{O}_{3}$ in the TTL with mixing ratios of $\sim 26 \mathrm{ppbv}$, similar to surface values, consistent with a long photochemical lifetime for ozone and smoothing of the profile via vertical mixing. At the coldest regions of the TTL (i.e., overshooting convection) temperature can fall well below $200 \mathrm{~K}$ (Gettelman and Forster, 2002).

\section{Model description}

The 3-D chemistry climate model CAM-Chem (Community Atmospheric Model with Chemistry, version 4.0), included into the CESM framework (Community Earth System Model, version 1.1.1), has been used for this study (Lamarque et al., 2012). The development of the benchmark CAMChem chemical mechanism is based on MOZART-4 (Model for Ozone and Related chemical Tracers, version 4) (Emmons et al., 2010). The current configuration includes an improved representation of stratospheric chemistry, considering heterogeneous processes for halogen species in polar stratospheric clouds from MOZART-3 (Kinnison et al., 2007; Wegner et al., 2013). CAM-Chem includes all of the physical parameterizations of CAM4 (Neale et al., 2013) and a finite volume dynamical core (Lin, 2004) for the tracer advection.

A model spin-up of 15 years considering constant boundary conditions representative of the 2000 decade was performed to ensure stratospheric stabilization of halogen sources, and the last of a 3-year long simulation was used to compute the bromine atmospheric burden for all sensitivity runs. A set of five global sensitivity simulations was performed with CAM-Chem to identify the contribution of 
each individual VSL species to the PGVSL and SGVSL stratospheric injection and the impact of transport within different tropical regions.

\subsection{CAM-Chem setup}

The setup used here considers a horizontal grid resolution of $1.9^{\circ}$ (latitude) $\times 2.5^{\circ}$ (longitude) and 26 hybrid vertical levels from the surface to approximately $40 \mathrm{~km}$ (Ordóñez et al., 2012; Saiz-Lopez et al., 2012). The model can be configured to perform either climatic simulations in "free running" mode (FR), where the physical state of the atmosphere is allowed to evolve independently following the hydrostatic equations, or in specified dynamics mode (SD), where offline meteorological fields are input into the model instead of calculated online. The SD procedure can allow for more precise comparisons between measurements of atmospheric composition and model output, and also allow comparing different sensitivity simulations where the chemical perturbations can be distinguished from the transport changes related to the physical state of the atmosphere (Lamarque et al., 2012).

To avoid dynamical perturbations, all sensitivities were performed in SD mode considering a high frequency meteorological input from a previous CAM-Chem FR climatic simulation. In this way, our CAM-Chem setup implies that we force the system to evolve as if it was a CTM (chemical transport model), resolving the complexity of the novel tropospheric/stratospheric halogen-chemistry mechanism while using the meteorological fields from a standard chemistryclimate simulation. Then, the horizontal wind components, air temperature, surface temperature, surface pressure, sensible and latent heat flux and wind stress are read from the input meteorological data set every $3 \mathrm{~h}$, while for time steps between the reading times, all fields are linearly interpolated to avoid jumps. Even when meteorologically CAM-Chem is used as a CTM, the model is allowed to proceed with an independent interannual chemical evolution of all tropospheric and stratospheric constituents, and a direct comparison of the oxidative capacity of different types of atmospheres (e.g, with tropospheric bromine chemistry and without it) can be addressed (see Lamarque et al. (2012) for a complete description of this specific type of configuration). The model was configured with prescribed sea surface temperatures (SST) and ice coverage for the 2000 decade (Rayner, 2003), so results are not representative of the meteorology of any specific year (i.e., the SD mode used here does not reproduce the specific characteristics of any of the El Niño/La Niña type events within the modeled period).

\subsubsection{Bromine chemistry scheme}

The model version used here includes a state-of-the-art organic and inorganic halogen (i.e., chlorine and bromine) photochemistry mechanism, considering both natural and anthropogenic sources, heterogeneous recycling, dry and wet deposition, both in the troposphere and stratosphere (Ordóñez et al., 2012). Rate constants have been updated to JPL-2010 (Jet Propulsion Laboratory, Sander et al., 2011) and IUPAC-2008 (International Union of Pure and Applied Chemistry; Atkinson et al., 2007, 2008). The chemical solver for all simulations was initialized with identical chemical boundary conditions for all species, and all the atmospheric oxidants were computed online at all times (i.e., without considering prescribed monthly $\mathrm{OH}$ fields as done in previous studies). Mayor improvements with respect to previous studies are related to heterogeneous recycling over ice particles and wet deposition processes; in Sects. 2.1.3 and 2.1.4 we present details of the implementation of these methods in CAM-Chem. For further details on bromine reactions with organic compounds, please see Table S1 in Ordóñez et al. (2012).

\subsubsection{VSL bromocarbon emissions inventory}

Geographically and seasonally distributed natural oceanic sources of VSL bromo- and iodocarbons have been included and validated in the model (Ordóñez et al., 2012). The top-down emissions inventory includes seasonality and geographical emission distributions based on parameterizations of chlorophyll $a$ satellite maps within the tropical oceans $\left(20^{\circ} \mathrm{N}-20^{\circ} \mathrm{S}\right)$ with a 2.5 coast-to-ocean emission ratio. In the extra tropics $\left(20-50^{\circ}\right.$ and $\left.50-90^{\circ}\right)$ a seasonal latitudinal variation is also considered. The current setup includes bromocarbon sources of $\mathrm{CHBr}_{3}, \mathrm{CH}_{2} \mathrm{Br}_{2}, \mathrm{CH}_{2} \mathrm{BrCl}, \mathrm{CHBr}_{2} \mathrm{Cl}$ and $\mathrm{CHBrCl}_{2}$, while iodocarbons species include $\mathrm{CH}_{3} \mathrm{I}, \mathrm{CH}_{2} \mathrm{I}_{2}$, $\mathrm{CH}_{2} \mathrm{ICl}$ and $\mathrm{CH}_{2} \mathrm{IBr}$. Hereafter, $\mathrm{SG}_{V S L}=\mathrm{CHBr}_{3}, \mathrm{CH}_{2} \mathrm{Br}_{2}$, $\mathrm{CH}_{2} \mathrm{BrCl}, \mathrm{CHBr}_{2} \mathrm{Cl}, \mathrm{CHBrCl}_{2}$ and $\mathrm{CH}_{2} \mathrm{IBr}$. The anthropogenic halogen lower boundary conditions are based on prescribed surface volume mixing ratios (vmr) of long-lived species (chlorofluorocarbons (CFCs), $\mathrm{CH}_{3} \mathrm{Cl}, \mathrm{CH}_{3} \mathrm{Br}$ and halons H1301, H1211, H1202, H2402) representative of year 2000. The long-lived inventory is based on Meinshausen et al. (2011), and has been recently used in the IPCC AR5 hindcast and projection simulations (Marsh et al., 2013).

The global Br mass flux from all VSL bromocarbons is approximately $630 \mathrm{Gg} \mathrm{Br} \mathrm{yr}^{-1}$, comparable to our previous model estimates (Ordóñez et al., 2012). Table 1 presents the individual emission contribution from each VSL considered, as well as their respective photochemical lifetime and the annual tropical surface mixing ratios that the inclusion of the emissions inventory generates. The geographical and seasonal representation of VSL sources constitutes a major improvement in CAM-Chem relative to studies performed with other models, where constant surface mixing ratios of VSL halocarbons are imposed at the lower level (Hossaini et al., 2012; Aschmann and Sinnhuber, 2013). Indeed, the current CAM-Chem setup includes constant surface mixing ratios only for long-lived species, because their long lifetimes ensure tropospheric homogenization. 
Table 1. Global annual oceanic flux, $\mathrm{SG}_{\mathrm{VSL}}$ abundances and atmospheric lifetime of VSL bromocarbons.

\begin{tabular}{|c|c|c|c|c|c|c|c|}
\hline Source gas & $\begin{array}{r}\text { Global flux } \\
\left(\mathrm{Gg} \mathrm{Br} \mathrm{yr}^{-1}\right)\end{array}$ & $\begin{array}{r}\text { Lifetime }^{\mathrm{a}} \\
\quad(\text { days })\end{array}$ & $\begin{array}{r}\text { Surface vmr } \\
(\text { pptv of } \mathrm{Br})\end{array}$ & $\begin{array}{c}\text { Lower TTL } \\
\text { (CAM-Chem) }\end{array}$ & $\begin{array}{r}\text { Lower TTL } \\
(\mathrm{WMO}-2010)\end{array}$ & $\begin{array}{r}\text { Upper TTL } \\
\text { (CAM-Chem) }\end{array}$ & $\begin{array}{r}\text { Upper TTL } \\
(\text { WMO-2010) }\end{array}$ \\
\hline $\mathrm{CHBr}_{3}$ & 505.6 & 17 & 5.5 & 1.89 & $(0.9-3.3)$ & 0.20 & $(0.03-0.87)$ \\
\hline $\mathrm{CH}_{2} \mathrm{Br}_{2}$ & 61.9 & 130 & 2.2 & 1.82 & $(1.54-2.30)$ & 1.5 & $(0.86-1.66)$ \\
\hline $\mathrm{CH}_{2} \mathrm{BrCl}$ & 6.2 & 145 & 0.3 & 0.21 & $(0.13-0.16)$ & 0.19 & $(0.1-0.12)$ \\
\hline $\mathrm{CHBr}_{2} \mathrm{Cl}$ & 15.1 & 56 & 0.4 & 0.24 & $(0.12-0.30)$ & 0.06 & $(0.02-0.22)$ \\
\hline $\mathrm{CHBrCl}_{2}$ & 11.0 & 46 & 0.2 & 0.14 & $(0.18-0.22)$ & 0.05 & $(0.11-0.14)$ \\
\hline $\mathrm{CH}_{2} \mathrm{IBr}$ & 31.6 & 0.1 & 0.01 & $\sim 0$ & Not reported & $\sim 0$ & Not reported \\
\hline Total & 631.4 & - & 8.5 & 4.30 & $(2.86-6.5)$ & 2.0 & $(1.1-3.2)$ \\
\hline
\end{tabular}

Adapted from Table 3 in Ordoñez et al. (2012) and Tables 1-7 from WMO-2010 (Montzka et al., 2011). The vmr for each species has been multiplied by their respective atomicity in order to represent the contribution to $\mathrm{Bry}_{\mathrm{y}}{ }^{\mathrm{a}}$ Lifetime for each species has been computed considering tropospheric loss by photolysis and reaction with $\mathrm{OH} .{ }^{\mathrm{b}}$ Values are in pptv of $\mathrm{Br}$, and have been averaged for the tropical latitudinal band $\left(20^{\circ} \mathrm{N}-20^{\circ} \mathrm{S}\right)$.

\subsubsection{Heterogeneous recycling}

Mechanistic improvements with respect to previous works (Ordóñez et al., 2012; Saiz-Lopez et al., 2012) are mainly based on the implementation of heterogeneous reactions of $\mathrm{HBr}, \mathrm{HOBr}$ and $\mathrm{BrONO}_{2}$ on tropospheric ice crystals and stratospheric aerosol surfaces. The inclusion of these reactions in CAM-Chem is based on the stratospheric implementation of heterogeneous recycling processes of Kinnison et al. (2007). Table S1 in the Supplement presents the full set of chlorine and bromine heterogeneous reactions occurring on different types of surfaces (i.e., stratospheric sulfate aerosols (SULF), nitric acid trihydrate (NAT), ice crystals (ICE) and sea-salt (SSLT) aerosols) with their respective reactive uptake coefficients $(\gamma)$. For the case of liquid sulfate aerosols in the stratosphere, a physically based treatment of heterogeneous kinetics $\left(\gamma_{\mathrm{SULF}}\right)$ following the framework of Hanson et al. (1994) is applied. All heterogeneous reactions occurring over ice surfaces with the exception of the ones for $\mathrm{HBr}$ were considered in our previous model configurations, although a different latitudinal/vertical efficiency below the tropopause was applied. Reactive uptake coefficients from Crowley et al. (2010), Ammann et al. (2013) and JPL-2010 (Sander et al., 2011) were used, unless stated otherwise.

Heterogeneous recycling reactions of $\mathrm{HOBr}, \mathrm{BrNO}_{2}$ and $\mathrm{BrONO}_{2}$ (and their equivalent chlorine compounds) are also considered to proceed on sea-salt aerosol surfaces ( $\mathrm{SA}_{\mathrm{SSLT}}$ ), considering that the rate limiting step is the uptake of halogen species on the aerosol surface (McFiggans et al., 2000). Within this approach we assume that the initial chloride and bromide existent in the bulk of the aerosol is large enough for the heterogeneous reaction to occur until the sea-salt aerosol is removed by washout. The sea-salt aerosol scheme considers four size bins for SSLT based on Mahowald et al. (2006). The formation of sea-salt aerosol in each size bin is a function of wind speed and humidity. The surface area density (SASSLT) used in this work is derived from the $\mathrm{NaCl}$ mass in each size bin and the effective radius of that bin. Sea salt is lost through dry deposition (including gravitational settling) and wet removal. Overall, the lifetime of sea salt is less than 1 day (see Mahowald et al., 2006 for details).

Note that this process represents an additional source of inorganic bromine and chlorine in the troposphere, independent from the oceanic flux of VSL halocarbons described above (i.e., these are nonstoichiometric reactions releasing $\mathrm{Cl}$ and $\mathrm{Br}$ atoms from sea-salt aerosols to the gas phase). An average depletion efficiency of 0.65 and 0.35 for bromide and chloride, respectively, has been considered following Ordóñez et al. (2012) (see Table S1). The annual SSLT bromine source yields $2.9 \mathrm{Tg} \mathrm{yr}^{-1}$ (53\% in the Southern Hemisphere) of which only $1.3 \mathrm{Tg} \mathrm{yr}^{-1}$ is released within the tropics. The contribution of SSLT heterogeneous reactions to the $\mathrm{Br}_{\mathrm{y}}$ loading for different geographical and vertical regions is analyzed in Sect. 3.4.

\subsubsection{Washout and ice-uptake}

The removal of halogen species in CAM-Chem occurs via washout and scavenging in water and ice clouds (Lamarque et al., 2012; Ordóñez et al., 2012), treating each of the $\mathrm{Br}_{\mathrm{y}}$ species independently. Both nucleation scavenging (rainout) and impaction scavenging (below-cloud washout) are implemented in the wet-removal schemes (see Lamarque et al., 2012 for details). The Henry law coefficients $\left(k_{\mathrm{H}}\right)$ for all bromine and chlorine species included in the model are shown in Table S2. Values are taken from the compilation of Henry's law constants of Sander (1999).

As nighttime reservoir species are more likely to be adsorbed by water/ice particles and removed from the gaseous phase (Crowley et al., 2010; Ammann et al., 2013), the modeled $\mathrm{Br}_{\mathrm{y}}$ loading in the TTL depends on the efficiency of the wet deposition schemes (such as in-cloud washout or removal by ice-uptake) relative to the heterogeneous recycling (Aschmann et al., 2011; Aschmann and Sinnhuber, 2013). CAM-Chem has been updated to include ice-uptake removal of halogen species following an equivalent procedure to that used by Neu and Prather (2012) for $\mathrm{HNO}_{3}$. The distinguishing features of the Neu and Prather scheme are 
related to the partitioning between in-cloud and below-cloud scavenging, the treatment of soluble gas uptake by ice and the overlap of condensate and precipitation within a column (Lamarque et al., 2012). Several sensitivity studies showed that an extremely efficient washout of $\mathrm{Br}_{\mathrm{y}}$ was artificially introduced in the case of considering ice-uptake for $\mathrm{HBr}, \mathrm{HOBr}$ and other bromine acids. Then, the halogen removal scheme in CAM-Chem was implemented with ice-uptake turned on for all chlorine species and for $\mathrm{BrONO}_{2}, \mathrm{BrNO}_{2}, \mathrm{BrCl}$ and $\mathrm{Br}_{2}$, considering that the removal of this reservoir halogen species occurs at liquid, ice, and mixed-phase clouds in the troposphere (Neu and Prather, 2012). For the rest of the $\mathrm{Br}_{\mathrm{y}}$ species (BrO, $\mathrm{HOBr}, \mathrm{HBr})$ the removal scheme considered only washout due to liquid clouds. An effective Henry's law washout efficiency considering the acid dissociation constant has been used for $\mathrm{HBr}$, the most abundant bromine reservoir in the lower troposphere $\left(\mathrm{K}_{\mathrm{H}}^{\text {eff }}(\mathrm{HBr})=7.2 \times 10^{13} \mathrm{M} \mathrm{atm}^{-1}\right.$, see Table S2). Uptake of $\mathrm{HBr}$ on liquid surfaces regulates the bromine scavenging within the MBL (marine boundary layer) and FT (free troposphere) in agreement with previous studies (Yang et al., 2005; Parrella et al., 2012).

Several studies have determined that the efficiency of $\mathrm{HBr}$ recycling on ice particles greatly surpasses the net uptake into the condensed phase, and the ice-mediated $\mathrm{HBr}$ losses within the TTL were estimated to represent at most $2 \%$ of the actual loss rate when a full chemistry scheme is considered (Aschmann et al., 2011). Then, even when inorganic bromine removal in the lower troposphere is highly dependent on $k_{\mathrm{H}}(\mathrm{HBr})$, its impact decreases within the TTL. Our approach is consistent with the modeling framework of Aschmann and Sinnhuber (2013), who report that in their reference setup the organic VSL sources "contribute completely to stratospheric bromine thus ruling out dehydration (within the TTL) as an efficient loss process for bromine". Indeed, due to the very fast photochemical time constants for the $\mathrm{Br}_{\mathrm{y}}$ system that rapidly equilibrate the steady-state abundance of all bromine species, bromine scavenging from the gaseous phase can proceed via the washout of other species besides $\mathrm{HBr}$. For example, the ice-uptake for $\mathrm{BrONO}_{2}$, one of the most abundant nighttime reservoirs in the absence of heterogeneous recycling, is considered to be infinitely efficient (i.e., it is instantaneously removed from the gaseous phase once it collides with an ice particle; see Sander and Crutzen, 1996; Sander, 1999) and controls the bromine burden in the upper TTL.

\subsection{Box-model configuration}

We used a photochemical box model (Salawitch et al., 2005) to compute the concentration of inorganic bromine species throughout a daily cycle, subject to the constraint that production and loss of each species is balanced over a $24 \mathrm{~h}$ period (diurnal photochemical steady state). The model includes a representation of 36 species constrained by specified values of $p, T, \mathrm{O}_{3}, \mathrm{Br}_{\mathrm{y}}, \mathrm{Cl}_{\mathrm{y}}, \mathrm{NO}_{\mathrm{y}}, \mathrm{H}_{2} \mathrm{O}, \mathrm{CH}_{4}, \mathrm{CO}$, and particle surface area. Reaction rates and absorption cross sections are from JPL-2010 (Sander et al., 2011). With the exception of the ozone sensitivity study (Sect. 3.3.1), all box-model simulations had been performed with an ambient $\mathrm{O}_{3}$ concentration of $25 \mathrm{ppbv}$, which is the expected ozone value existent in the TTL within strong convective regions. The abundance of $\mathrm{H}_{2} \mathrm{O}$ is set at $12.5 \mathrm{ppmv}$ (parts per million by volumne), the saturation mixing ratio for $T=200 \mathrm{~K}$ and $p=130 \mathrm{hPa}$. Values of $\mathrm{NO}_{\mathrm{y}}$ are based on observations (Murphy et al., 1993). The abundance of CO is based on measurements in the subtropical upper troposphere (Marcy et al., 2004) and the value of $\mathrm{CH}_{4}$ is set to contemporary surface levels. Surface area for sulfate (SASULF) had been estimated from SAGE II (Stratospheric Aerosol and Gas Experiment) measurements, obtained during July 2005. SAICE was found assuming a condensation of $12.5 \mathrm{ppmv}$ of $\mathrm{H}_{2} \mathrm{O}$ onto 10 particles $\mathrm{cm}^{-3}$, resulting in $7.5 \mu \mathrm{m}$ radius particles. Clearly, $\mathrm{SA}_{\mathrm{ICE}}$ in the TTL is highly variable. Our calculations are designed to represent the fact that typically, $\mathrm{SA}_{\mathrm{ICE}} \gg \mathrm{SA}_{\mathrm{SULF}}$ in the TTL (see Fig. 10). Reactive uptake coefficients for the heterogeneous recycling reactions were taken from JPL2010 (Sander et al., 2011), based on the laboratory measurements of Abbatt (1994). Unless stated otherwise, all simulations are performed for latitude $=10^{\circ} \mathrm{N}$ and solar declination $=20^{\circ}$, and numerical values for all model inputs are as follows: $p=130 \mathrm{hPa}, T=200 \mathrm{~K}, \mathrm{H}_{2} \mathrm{O}=12.5 \mathrm{ppmv}, \mathrm{CH}_{4}=$ 1.77 ppmv, $\mathrm{CO}=60 \mathrm{ppbv}, \mathrm{Br}_{\mathrm{y}}=4 \mathrm{pptv}$ (parts per trillion by volume), $\mathrm{NO}_{\mathrm{y}}=400 \mathrm{pptv}$ and $\mathrm{O}_{3}=25$ ppbv. Model output for the box-model simulations is shown as $[\mathrm{X}] /\left[\mathrm{Br}_{\mathrm{y}}\right]$, where $[\mathrm{X}]$ represents the mixing ratio of specific inorganic bromine species. We conducted simulations for $\mathrm{Br}_{\mathrm{y}}=4 \mathrm{pptv}$, but all results shown here are extremely insensitive to the particular choice of $\mathrm{Br}_{\mathrm{y}}$, for values ranging from at least 1 to 10 pptv. Box model results are insensitive to assumptions regarding values of $\mathrm{H}_{2} \mathrm{O}, \mathrm{SA}_{\mathrm{ICE}}$, and $\mathrm{CO}$ in the TTL, provided some reasonable value is used.

\section{Results and discussions}

All the CAM-Chem results shown here include an ocean mask below $3 \mathrm{~km}$ altitude to avoid considering grids above land that could produce artificially reduced vertical profiles within the MBL. Besides the standard $24 \mathrm{~h}$ averaged streaming, time-dependent output for day and night has been generated considering the noon (11:30-12:30) and midnight (23:30-00:30) local times, respectively, for all latitudes and longitudes. Tropical averages have been computed between $20^{\circ} \mathrm{N}$ and $20^{\circ} \mathrm{S}$, while the Western Pacific (WP) warm pool area is defined by the Equator $\left(0^{\circ}\right)$, the $20^{\circ} \mathrm{N}$ parallel, and the 120 and $165^{\circ} \mathrm{E}$ meridians (see black rectangle in Fig. 5). 


\subsection{The partitioning of inorganic and organic bromine}

The vertical distribution of annually averaged inorganic bromine species within the tropics $\left(20^{\circ} \mathrm{N}-20^{\circ} \mathrm{S}\right)$ at noon and midnight is shown in Fig. 1a and b, respectively. Figure $1 \mathrm{c}$ illustrates the $24 \mathrm{~h}$ mean inorganic and organic contributions to the total bromine budget of the tropical atmosphere. Our model shows a total $\left(\mathrm{Br}_{\text {total }}=\mathrm{Br}_{\text {org }}+\mathrm{Br}_{\mathrm{y}}\right)$ stratospheric bromine loading of $\sim 21 \mathrm{pptv}$, within the range of values (19.5-24.5 pptv) inferred from measurements of stratospheric $\mathrm{BrO}$ reported in the last WMO ozone assessment report (Montzka et al., 2011). Below the tropopause, $\mathrm{Br}_{\text {org }}$ (defined as $\mathrm{Br}_{\text {Halons }}+\mathrm{CH}_{3} \mathrm{Br}+\mathrm{SG}_{\mathrm{VSL}}$ ) is the dominant form of bromine because the abundant long-lived bromocarbons have not yet decomposed. Within this organic portion, $\sim 4.3 \mathrm{pptv}$ of $\mathrm{SG}_{\mathrm{VSL}}$ reaches the lower TTL, where 2.3 pptv are transformed to active $\mathrm{Br}_{\mathrm{y}}$ before stratospheric injection (see Fig. 2 and Table 1 for details on the individual SGVSL partitioning). In strong convective regions the faster transport increases the total amount of $\mathrm{SG}_{\mathrm{VSL}}$ reaching the lower TTL relative to the tropical annual average: our model results show an enhancement of $0.8 \mathrm{pptv}$ or $\sim 20 \%$ for the WP region, in agreement with recent measurements performed in the upper troposphere (Sala et al., 2014). In the middle and upper stratosphere (i.e., above $\sim 25 \mathrm{~km}$ altitude), inorganic bromine dominates because of photodissociation of any organic compounds that cross the tropopause (Fig. 1c).

$\mathrm{HBr}$ is the dominant inorganic bromine species in the MBL, FT and lower TTL both during daytime and at night (Fig. 1a, b). Then, the removal rate of $\mathrm{HBr}$ controls the total amount of $\mathrm{Br}_{\mathrm{y}}$ that reaches the lower TTL and can subsequently be injected into the stratosphere (Yang et al., 2005; Sinnhuber and Folkins, 2006; Parrella et al., 2012; Aschmann and Sinnhuber, 2013). In the upper TTL, the $\mathrm{HBr} / \mathrm{Br}_{\mathrm{y}}$ ratio is $\sim 0.1$ due to fast heterogeneous recycling over icecrystals that release reactive bromine back to the gas phase; so bromine washout is controlled by the scavenging of nighttime reservoirs. On an annual average, noontime $\mathrm{BrO}$ values in the FT are $\sim 0.2$ pptv within the tropics (Fig. 1a) and in the range of 0.2-0.4 pptv for midlatitudes (Fig. 6), with higher values of up to a few pptv calculated for certain coastal locations within the MBL, in agreement with previous studies (Yang et al., 2005; Parrella et al., 2012; SaizLopez et al., 2012). The modeled tropical vertical profiles of $\mathrm{BrO}$ are in excellent agreement with balloon measurements performed in the tropical regions where $\mathrm{BrO}$ concentrations of $(2.0 \pm 1.5) \mathrm{pptv}$ for the local tropopause $(17 \mathrm{~km})$ and (3.2 \pm 1.6$)$ pptv at $18 \mathrm{~km}$ were observed, with very low, or even negligible, $\mathrm{BrO}$ concentrations ( $<1 \mathrm{ppt})$ for the lower, middle and upper troposphere (Dorf et al., 2008).

During nighttime, $\mathrm{BrCl}, \mathrm{HOBr}$ and $\mathrm{BrONO}_{2}$ dominate the inorganic bromine budget in the TTL and stratosphere, while $\mathrm{HBr}$ dominates in the FT and MBL (Fig. 1b). Large-volume mixing ratios of the diatomic $\mathrm{Br}_{2}$ and $\mathrm{BrCl}$ species are maintained in the first few kilometers above the oceans due to the occurrence of heterogeneous recycling reactions over seasalt aerosols (see Table S1). As the average depletion for bromide is larger than for chloride, the calculated abundance of $\mathrm{Br}_{2}$ surpasses that of $\mathrm{BrCl}$ in the MBL. Their abundance decrease rapidly with increasing altitude following the vertical profiles of SASSLT (see Fig. 10a). The abundance of $\mathrm{BrCl}$ in the upper TTL increases due to the efficient heterogeneous recycling of inorganic chlorine reservoirs (i.e., $\mathrm{HCl}$ ), which turns out to be more efficient than the $\mathrm{Br}_{2}$ production via $\mathrm{HOBr}+\mathrm{HBr}$ (see Sect. 3.3). The potential importance of $\mathrm{BrCl}$ is quite uncertain due to two factors: the contribution of VSL chlorocarbons to $\mathrm{Cl}_{\mathrm{y}}$ in the upper TTL is not well constrained by observations but is likely between 0 and $50 \mathrm{pptv}$ (Montzka et al., 2011); the particle habitat is highly variable and the $\mathrm{ClO} / \mathrm{Cl}_{\mathrm{y}}$ ratio is quite sensitive to temperature. A box-model sensitivity analysis of the recycling processes affecting the partitioning of nighttime bromine reservoirs is given in Sect. 3.3.

The tropical annual vertical profiles for all VSL bromocarbons and their overall SGVSL contribution are shown in Fig. 2a. The equivalent profiles computed for February within the WP region are presented in Fig. $2 b$. The $\mathrm{Br}_{\mathrm{y}}$ loading within the TTL depends primarily on the release of reactive bromine from $\mathrm{CHBr}_{3}$ and $\mathrm{CH}_{2} \mathrm{Br}_{2}$, which are the most abundant species and represent more than $85 \%$ of $\mathrm{SG}_{\mathrm{VSL}}$ in the lower TTL (Montzka et al., 2011). $\mathrm{CHBr}_{3}$ is removed mainly by photolysis (it has the smallest lifetime of VSL bromocarbons), releasing an annual average of $1.7 \mathrm{pptv} \mathrm{Br}$ atoms into the gaseous inorganic phase before being transported to the stratosphere (see Table 1). In comparison, only $\sim 17 \%$ of the bromine contained in $\mathrm{CH}_{2} \mathrm{Br}_{2}$ that reaches the lower TTL is released below the cold point tropopause $(\sim 17 \mathrm{~km})$. Within the WP region, where the strength of convective transport is increased, $5.1 \mathrm{pptv}$ of $\mathrm{SG}_{\mathrm{VSL}}$ reach the lower TTL. Also, due to the faster vertical transport, the photochemical loss of $\mathrm{CHBr}_{3}$ within the TTL is reduced by $\sim 35 \%$, releasing only $\sim 1.1$ pptv $\mathrm{Br}$ before stratospheric injection occurs. Comparatively, only $5 \%$ of $\mathrm{CH}_{2} \mathrm{Br}_{2}$ is decomposed before stratospheric injection.

\subsection{The tropical ring of atomic bromine}

Daytime levels of atomic $\mathrm{Br}$ increase significantly within the TTL due to the low abundance of ozone and cold conditions, which restrict formation of $\mathrm{BrO}$ by the $\mathrm{Br}+\mathrm{O}_{3}$ reaction. As a result we simulate a daytime "tropical ring of atomic bromine" extending from $30^{\circ} \mathrm{N}$ to $30^{\circ} \mathrm{S}$ (Fig. 3), where $\mathrm{Br}$ atoms constitute a major portion of $\mathrm{Br}_{\mathrm{y}}$. Within this tropical ring, annual average $\mathrm{Br}$ maximizes at $\sim 1.3 \mathrm{pptv}$ near the cold point tropopause, representing up to $30 \%$ of the total annually averaged $\mathrm{Br}_{\mathrm{y}}$ within the tropics (see contour lines in Fig. 3).

The tropical ring of atomic $\mathrm{Br}$ is a photochemical phenomenon. It exists only on the illuminated portion of the earth, so it circles the tropics with the sun. The tropical ring 


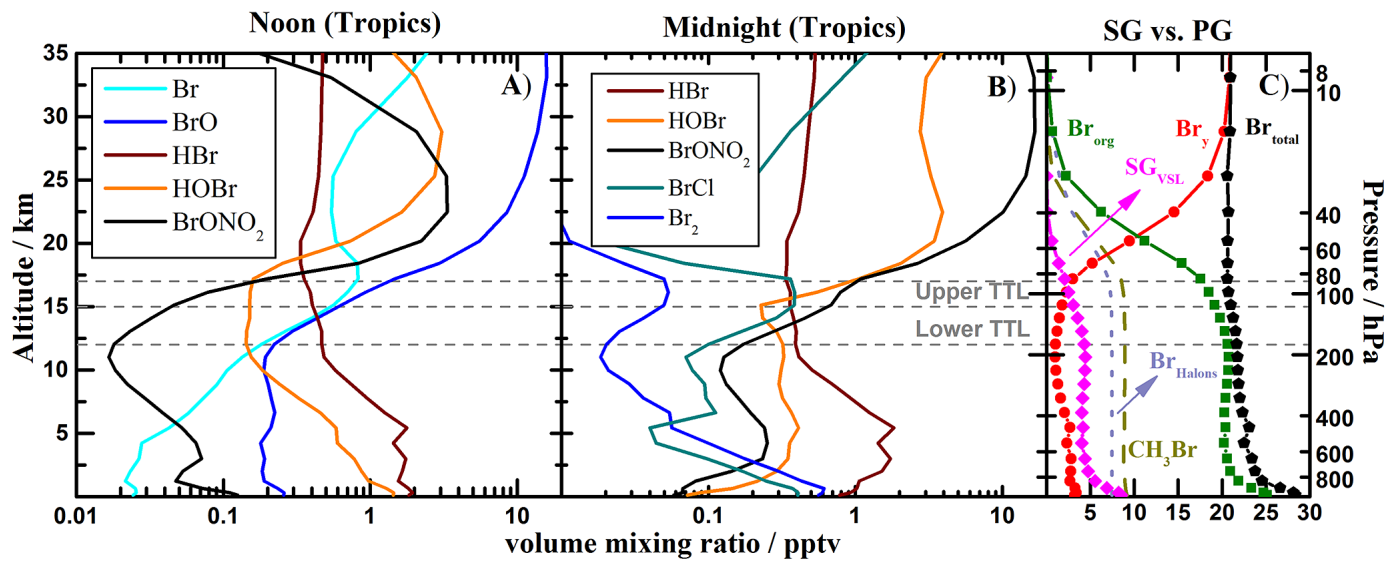

Figure 1. Annual vertical profile abundances of organic and inorganic bromine species within the tropics $\left(20^{\circ} \mathrm{N}-20^{\circ} \mathrm{S}\right):(\mathbf{a})$ main $\mathrm{Br}$ y $\mathrm{species}$ at noon; (b) main $\mathrm{Br}_{\mathrm{y}}$ species at midnight; and (c) $24 \mathrm{~h}$ average contribution of organic and inorganic species to total bromine. The horizontal dotted lines represent the approximate location of the TTL.

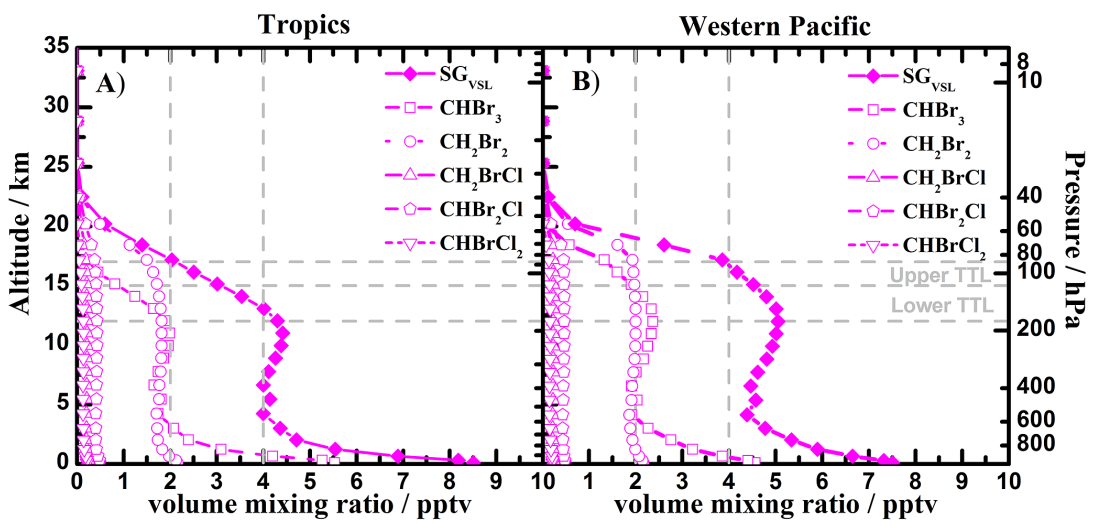

Figure 2. Vertical profile abundances of the five VSL bromocarbons considered in CAM-Chem for the tropical annual average (a) and the Western Pacific region (b). All halocarbon abundances are multiplied by their respective atomicity in order to represent their contribution to $\mathrm{Br}_{\mathrm{y}}$ after photolysis or reaction with $\mathrm{OH}$. The total organic $\mathrm{SG}_{\mathrm{VSL}}$ contribution is also shown by the filled diamonds.

extends approximately from 15 to $19 \mathrm{~km}$, driven by vertical variations in ozone and temperature. The height thickness is delimited by temperatures colder than $\sim 200 \mathrm{~K}$, with $\mathrm{O}_{3}$ mixing ratios ranging between $\sim 25$ and $\sim 500 \mathrm{ppbv}$ at the bottom and top boundaries, respectively. Below the lower limit of the ring, the ambient temperature is high enough (e.g., > $220 \mathrm{~K}$ ) for the highly exothermic $\mathrm{Br}+\mathrm{O}_{3}$ reaction (Sander et al., 2011) to proceed efficiently. Above the ring, in the lower stratosphere, ozone abundances of a few ppmv and warmer conditions lead to the rapid formation of $\mathrm{BrO}$ through $\mathrm{Br}+\mathrm{O}_{3}$. It is worth recalling that due to its strong ozone and temperature dependence, the proposed tropical ring of atomic bromine should occur as an inhomogeneous ring of $\mathrm{Br}$ that follows the illuminated portion of the earth with variable mixing ratios at various longitudes, latitudes and altitudes.

The existence of the atomic $\mathrm{Br}$ ring is a direct consequence of the $\mathrm{O}_{3} / T$ dependences described above, and as such, presents a marked seasonality and geographical distribution (see Figs. 3c and 5a). The maximum abundances of atomic $\mathrm{Br}$ within the tropical ring are coincident with low ozone regions, i.e., in geographical areas of extremely strong convection such as the tropical WP warm pool (Ashfold et al., 2012; Brinckmann et al., 2012), where $\mathrm{O}_{3}$-poor air masses originating from the MBL are rapidly transported to the lower TTL (Folkins and Braun, 2002). When $\mathrm{O}_{3}$ falls below a critical level, the loss of atomic bromine occurs primarily via reaction with the formaldehyde ( $\mathrm{HCHO})$. Our results indicate atomic Br levels of up to 3 pptv may occur in the WP region during periods of vigorous convection (Fig. 4). Due to the fast vertical transport during convective events (hours-days), $\mathrm{SG}_{\mathrm{VSL}}$ compounds are not completely decomposed, and an additional source of $\mathrm{Br}_{\mathrm{y}}$ in the lower TTL of the WP region arises from the detrainment of bromine-rich air masses entrained in the MBL and lower troposphere. Model sensitivities (see Sect. 3.4) indicate that during strong convection 



Figure 3. The "tropical ring of atomic bromine": (a) annual zonal average; (b) annual meridional average abundance of atomic Br within the tropics $\left(20^{\circ} \mathrm{N}-20^{\circ} \mathrm{S}\right)$; and (c) seasonal evolution of the zonally averaged atomic $\mathrm{Br}$ ring within the tropics. The color scale represents noontime volume mixing ratios (pptv) while black contour lines show the percentage contribution of atomic $\mathrm{Br}$ to $\mathrm{Br}_{\mathrm{y}}$.

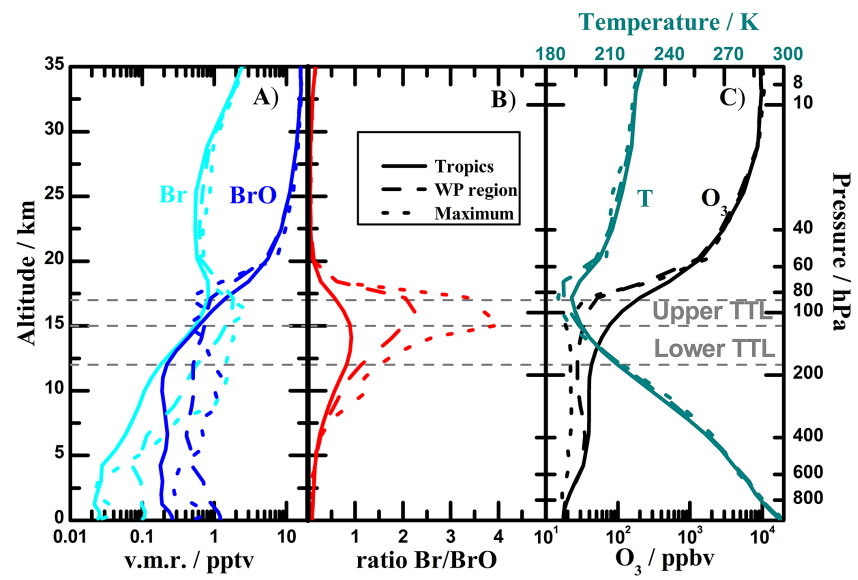

Figure 4. Vertical noontime profiles of $\mathrm{Br}$ and $\mathrm{BrO}$ vmr (a), the $\mathrm{Br} / \mathrm{BrO}$ ratio (b), and $\mathrm{T}$ and $\mathrm{O}_{3}(\mathbf{c})$ in the tropics. Vertical profiles have been averaged over different regions and time periods: (solid) annual tropical averages $\left(20^{\circ} \mathrm{N}-20^{\circ} \mathrm{S}\right)$; (dashed) WP region during February; (dotted) at the midpoint of a strong convective cell within the WP during a 3-day period in February.

within the WP region, the efficient sea-salt recycling occurring up to a height of $\sim 3 \mathrm{~km}$ increases significantly the $\mathrm{Br}_{\mathrm{y}}$ loading in the lower troposphere (see Fig. 11), and approximately half of the $\mathrm{Br}_{\mathrm{y}}$ released in the MBL can reach the lower TTL $\left(\mathrm{Br}_{\mathrm{y}}^{\mathrm{MBL}} \approx 7.9 \mathrm{pptv}\right.$ and $\left.\mathrm{Br}_{\mathrm{y}}^{12 \mathrm{~km}} \approx 3.6 \mathrm{pptv}\right)$. The increase in atomic bromine levels within the middle and upper troposphere directly influences the lifetime of elemental mercury against oxidation via $\mathrm{Hg}+\mathrm{Br}$ (Holmes et al., 2006, 2010).

\subsubsection{The $\mathrm{Br} / \mathrm{BrO}$ ratio in the TTL}

Even though $\mathrm{BrO}$ is the most abundant species throughout the tropics on an annual average (Fig. 1a), a ratio of $\mathrm{Br} / \mathrm{BrO}>1$ will occur in key areas. The abundance of atomic $\mathrm{Br}$ surpasses $\mathrm{BrO}$ in regions of the TTL where temperatures and $\mathrm{O}_{3}$ levels range from 190 to $220 \mathrm{~K}$ and from 50 to $25 \mathrm{ppbv}$, respectively (see Figs. 4 and 5). As
$\mathrm{Br}$ and $\mathrm{BrO}$ establish a photochemical steady state, their ratio can be approximated by the $\mathrm{BrO}$ photolysis $\left(J_{\mathrm{BrO}}\right)$ and the Arrhenius type $\mathrm{Br}+\mathrm{O}_{3}$ reaction $\left(k_{\mathrm{Br}+\mathrm{O}_{3}}\right)$, i.e., $[\mathrm{Br}] /[\mathrm{BrO}]=J_{\mathrm{BrO}} /\left(k_{\mathrm{Br}+\mathrm{O}_{3}}\left[\mathrm{O}_{3}\right]\right)$. A box-modeling analysis of the sensitivity of the partitioning between $\mathrm{Br}$ and $\mathrm{BrO}$ to ozone is given in Sect. 3.3.1.

The $\mathrm{Br} / \mathrm{BrO}$ ratio peaks in regions with $\mathrm{O}_{3}<40$ ppbv and $T<190 \mathrm{~K}$, while for regions with $\mathrm{O}_{3}>60 \mathrm{ppb}$ and $T>200 \mathrm{~K}$ within the tropics a ratio of $\mathrm{Br} / \mathrm{BrO}<1$ is found. The altitude where the $\mathrm{Br} / \mathrm{BrO}$ ratio peaks is usually located just below the maximum level of atomic $\mathrm{Br}$, as a consequence of a compromise between the decrease of temperature and the increase of $\mathrm{O}_{3}$ towards the lower stratosphere.

The magnitude of the $\mathrm{Br} / \mathrm{BrO}$ ratio peak strongly depends on season and geographical region, due to the changes in oceanic sources and vertical transport. Figure $5 \mathrm{a}-\mathrm{c}$ show the modeled geographic distributions of $\mathrm{Br}, \mathrm{BrO}$ and $\mathrm{Br} / \mathrm{BrO}$ ratio at the top of the TTL $(\sim 17 \mathrm{~km})$ for February. At this altitude, monthly averaged values of $\mathrm{Br} / \mathrm{BrO} \sim 2.5$ are found for the WP region (see Fig. 4). The modeled ozone vertical profiles in the WP are in very good agreement with ozonesonde measurements of Rex et al. (2014), who reported that ozone loss in the boundary layer combined with convectively driven vertical mixing in the WP region is the most likely explanation for the very low $\mathrm{O}_{3}$ mixing ratios found in the upper troposphere. The WP is a critical region: during the Northern Hemisphere winter, a majority of air parcels that are lofted to the $\theta_{\mathrm{CPT}}=380 \mathrm{~K}$ level by rapid convection (which marks likely future ascent to the stratosphere) detrain in the TTL (Bergman et al., 2012). For individual events of vigorous convection within the $\mathrm{WP}$, atomic $\mathrm{Br}$ represents $\sim 60 \%$ of daytime $\mathrm{Br}_{\mathrm{y}}$ and a maximum $\mathrm{Br} / \mathrm{BrO}$ ratio of $\sim 4$ is found (see Fig. 4b).

Figure 6 shows the zonal average vertical distribution of $\mathrm{BrO}$ abundances between $60^{\circ} \mathrm{N}$ and $60^{\circ} \mathrm{S}$, similar to Fig. 3a for atomic $\mathrm{Br}$. The characteristic latitudinal variation of the tropopause is clearly defined by the change in $\mathrm{BrO}$ abundances: within the tropics, the altitude of the tropopause is $\sim 17 \mathrm{~km}$ or $\sim 100 \mathrm{hPa}$ while for the midlatitudes it re- 

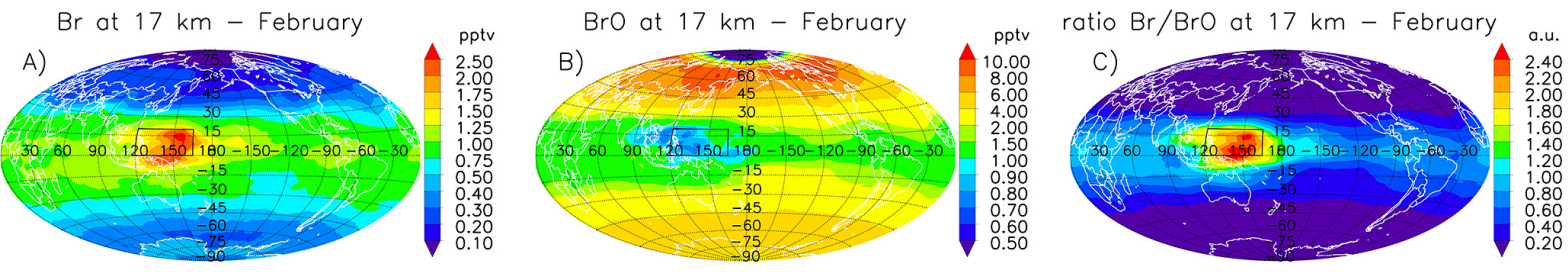

$\mathrm{O}_{3}$ at $17 \mathrm{~km}$ - February

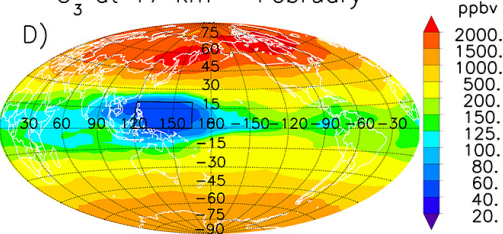

Temperature at $17 \mathrm{~km}$ - February
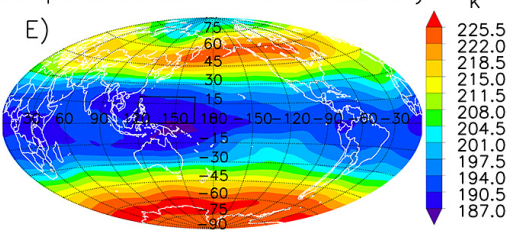

$\mathrm{Br}$ at $17 \mathrm{~km}$ - February

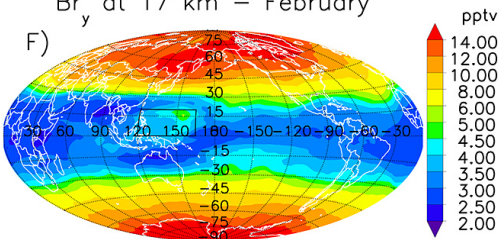

Figure 5. Average noontime geographical distribution of atmospheric bromine, ozone and temperature at $17 \mathrm{~km}$ during February: (a) atomic $\mathrm{Br}$; (b) $\mathrm{BrO}$; (c) $\mathrm{Br} / \mathrm{BrO}$ ratio; (d) ozone; (e) temperature; and (f) $\mathrm{Br}_{\mathrm{y}}$. The location of the WP region, also considered to compute the vertical profiles of Figs. 2, 4, 10 and 11, is outlined in black.

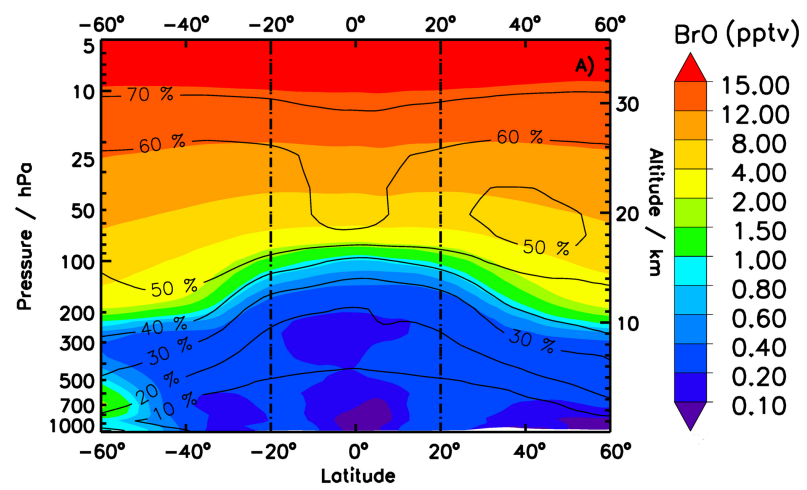

Figure 6. Annual zonal average $\mathrm{BrO}$ distributions between $60^{\circ} \mathrm{N}$ and $60^{\circ} \mathrm{S}$. The color scale represents absolute values (pptv), while black contour lines show the percentage contribution of $\mathrm{BrO}$ to $\mathrm{Br}_{\mathrm{y}}$.

mains between 10 and $12 \mathrm{~km}(\sim 200 \mathrm{hPa})$. Within the FT, $\mathrm{BrO}$ abundances remain below $0.4 \mathrm{pptv}$ on an annual average, while in the stratosphere up to $70 \%$ of $\mathrm{Br}_{\mathrm{y}}$ is due to $\mathrm{BrO}$, with a clear stratification as we move up to the higher levels. At the top of the model $(\sim 35 \mathrm{~km})$, daytime $\mathrm{BrO}$ reaches 16 pptv, and together with $\mathrm{BrONO}_{2}$ and $\mathrm{HOBr}$ are the most abundant species in the sunlit stratosphere.

Even when the geographic distributions of $\mathrm{Br}$ and $\mathrm{BrO}$ differ (Fig. 5a, b), the $\mathrm{Br} / \mathrm{BrO}$ ratio follows the spatial patterns of $\mathrm{O}_{3}$ and temperature (Fig. 5d, e) and defines the inhomogeneous extension of the tropical ring. This confirms that the $\mathrm{Br} / \mathrm{BrO}$ ratio is nearly independent of the total amount of $\mathrm{Br}_{\mathrm{y}}$ (Fig. 5f) as expected due to the rapid photochemical time constants of the $\mathrm{Br}_{\mathrm{y}}$ system (Saiz-Lopez and von Glasow, 2012). Notwithstanding uncertainties in heterogeneous reactions and removal processes, all the global sensitivity simulations presented in Sect. 3.4 predict the existence of the tropical ring of atomic bromine and a pronounced $\mathrm{Br} / \mathrm{BrO}$ peak within the TTL. Hence, measurements of the abundance of daytime $\mathrm{Br}$, in addition to that of $\mathrm{BrO}$, would be valuable for quantifying the bromine budget in the TTL and the injection of $\mathrm{Br}_{\mathrm{y}}$ into the stratosphere.

\subsection{Sensitivity to heterogeneous recycling: a box-modelling approach}

The species $\mathrm{HBr}, \mathrm{HOBr}$ and $\mathrm{BrONO}_{2}$ are soluble and likely to be absorbed by aerosol or liquid cloud particles (Iraci et al., 2005; Abbatt et al., 2012; Saiz-Lopez and von Glasow, 2012), and the reactive uptake of $\mathrm{HBr}, \mathrm{HCl}$ and $\mathrm{HOBr}$ has been observed to proceed over ice (Abbatt, 1994). Depending on the local microphysical environment, sedimentation of these particles and dehydratation could represent an efficient sink for $\mathrm{Br}_{\mathrm{y}}$, preventing the decomposition products of biogenic bromocarbons from reaching the lower stratosphere (Sinnhuber and Folkins, 2006) or global troposphere (Yang et al., 2005). However, the efficiency of aerosol/cloud washout of $\mathrm{Br}_{\mathrm{y}}$ is likely altered by heterogeneous reactions that release bromine to the gas phase (Iraci et al., 2005; Salawitch, 2006; Sinnhuber and Folkins, 2006), and several recent global modeling studies have included $\mathrm{HBr}$ heterogeneous recycling with different efficiencies and highlighted its importance (Yang et al., 2005; Aschmann et al., 2011; Parrella et al., 2012; Aschmann and Sinnhuber, 2013). Here we go a step forward and, instead of addressing the bromine removal efficiency, we focus on the important changes in the nighttime partitioning of bromine reservoirs due to the inclusion (or not) of heterogeneous recycling reactions. Table 2 presents a complete set of kinetic model sensitivities aimed at evaluating the uncertainties of such processes for atmospheric conditions representative of the cold point tropopause of the tropical WP. Results are shown for various model runs, with different assumptions for particle surface area (SA) and total inorganic chlorine $\left(\mathrm{Cl}_{\mathrm{y}}\right)$ affecting the heterogeneous 
reactions:

$\mathrm{HOBr}+\mathrm{HBr} \rightarrow \mathrm{Br}_{2}+\mathrm{H}_{2} \mathrm{O}$,

$\mathrm{HOBr}+\mathrm{HCl} \rightarrow \mathrm{BrCl}+\mathrm{H}_{2} \mathrm{O}$.

Once inorganic bromine is produced from the decomposition of biogenic bromine compounds, we expect the chemistry to equilibrate rapidly to a state similar to one of those shown in Fig. 7. In all cases, the nighttime reservoirs are converted almost entirely to $\mathrm{Br}$ and $\mathrm{BrO}$ during each sunlit cycle, with $\mathrm{HBr}$ being the only other species potentially present during daytime. The particular state will be determined by local ambient levels of $\mathrm{O}_{3}$, temperature, $\mathrm{Cl}_{\mathrm{y}}$, and particle surface area.

Figure $7 \mathrm{~b}$ shows the diurnal variation of $\mathrm{Br}_{\mathrm{y}}$ species for Run_la, which assumes the presence of only sulfate aerosols (SASULF) and that $\mathrm{Cl}_{\mathrm{y}}=0$. The calculated abundance of $\mathrm{BrONO}_{2}$ displays a rapid rise during evening twilight, because the nighttime buildup of $\mathrm{NO}_{2}$ occurs coincidently with the presence of $\mathrm{BrO}$. However, $\mathrm{BrONO}_{2}$ is converted to $\mathrm{HOBr}$ by heterogeneous hydrolysis, with a lifetime of several hours (Lary et al., 1996). Prior to sunrise, $\mathrm{HOBr}$ is the dominant nighttime reservoir, while the $\mathrm{Br}_{2}$ produced by $\mathrm{Re}$ action (R1) constitutes about $20 \%$ of total $\mathrm{Br}_{\mathrm{y}}$. If the recycling reaction is turned off ( $R u n \_0$, where $\left.\gamma_{\mathrm{HOBr}+\mathrm{HBr}}=0\right)$, significant levels of $\mathrm{HBr}$ are present at all times (Fig. 7a) and the lowest values of atomic $\mathrm{Br}$ are found. However, in the presence of large areas of ice particles ( $\left.\mathrm{SA}_{\mathrm{ICE}}\right)$, the heterogeneous Reaction (R1) acts as a rapid sink of $\mathrm{HBr}$, resulting in nearly complete nighttime conversion of all $\mathrm{Br}_{\mathrm{y}}$ to $\mathrm{HOBr}$ (Fig. 7c). Reaction (R1) has been observed to proceed on ice (Abbatt, 1994) and sulfate surfaces (Iraci et al., 2005) under laboratory settings, so it is likely that the conditions of Run_O are unrealistic. Hence, very low abundances of $\mathrm{HBr}$ are expected to be present in the TTL. Figure $7 \mathrm{~d}$ shows calculated lifetimes for photochemical loss of $\mathrm{HBr}$; the longest time constant is for Run_O, with $\mathrm{HBr}$ removal becoming progressively faster for Run_la and Run_lb.

The nighttime partitioning of $\mathrm{Br}_{\mathrm{y}}$ species is also sensitive to the possible presence of trace chlorine. Background chlorine levels in the FT and lower TTL are $<10$ pptv due to the long photolytic lifetimes of $\mathrm{CFCs}$ and $\mathrm{CH}_{3} \mathrm{Cl}$, and the small contributions from VSL chlorocarbons (Montzka et al., 2011). Despite this, stratospheric intrusion events are frequent within the TTL, and observations of $\mathrm{Cl}_{\mathrm{y}}$ as high as $50 \mathrm{pptv}$ have been reported in the subtropical upper troposphere (Marcy et al., 2004). Additionally, Mébarki et al. (2010) have determined a background $\mathrm{HCl}$ mixing ratio of $\sim 20-30$ pptv in the upper TTL not influenced by tropospheric nor stratospheric air. The presence of this much $\mathrm{Cl}_{\mathrm{y}}$ results in rapid conversion of $\mathrm{HOBr}$ to $\mathrm{BrCl}$, due to Reaction (R2). As shown in Fig. 7e and f, $\mathrm{BrCl}$ will likely be the dominant nighttime $\mathrm{Br}_{\mathrm{y}}$ reservoir whenever $\mathrm{Cl}_{\mathrm{y}} \gg \mathrm{Br}_{\mathrm{y}}$ (for Run_2a, $\mathrm{Br}_{2}$ is the other nighttime reservoir). Abundances of $\mathrm{Cl}_{\mathrm{y}}$ large enough to drive nighttime $\mathrm{Br}_{\mathrm{y}}$ almost entirely into $\mathrm{BrCl}$ might be supplied either by decomposition of VSL
Table 2. Description of inputs for various box-model simulations.

\begin{tabular}{llrrr}
\hline Simulation & $\begin{array}{l}\text { Particle } \\
\text { type }\end{array}$ & $\begin{array}{r}\text { Surface area (SA) } \\
\left(\mathrm{cm}^{2} / \mathrm{cm}^{3}\right)\end{array}$ & $\gamma_{\mathrm{HOBr}+\mathrm{HBr}}$ & $\begin{array}{r}\mathrm{Cl}_{\mathrm{y}} \\
(\mathrm{pptv})\end{array}$ \\
\hline Run_0 & Sulfate & $2.9 \times 10^{-8}$ & 0.0 & 0.0 \\
Run_1a & Sulfate & $2.9 \times 10^{-8}$ & 0.25 & 0.0 \\
Run_1b & Ice & $1.8 \times 10^{-5}$ & 0.1 & 0.0 \\
Run_2a & Sulfate & $2.9 \times 10^{-8}$ & 0.25 & 50.0 \\
Run_2b & Ice & $1.8 \times 10^{-5}$ & 0.1 & 50.0 \\
\hline
\end{tabular}

chlorocarbons, or by irreversible mixing of a small portion of stratospheric air into the upper troposphere (Marcy et al., 2004).

\subsubsection{Dependence of $\mathrm{Br}_{\mathrm{y}}$ partitioning on ozone and temperature}

Figure 8 shows the box-model calculated noontime abundance of $\mathrm{Br}_{\mathrm{y}}$ species, as a function of $\mathrm{O}_{3}$ for Run_la. The vertical dashed lines denote $\mathrm{O}_{3}$ mixing ratios of 20 and 30 ppbv, values commonly present near convective outflow in the TTL of the WP region (Rex et al., 2014). For these levels of $\mathrm{O}_{3}$, atomic $\mathrm{Br}$ is the dominant inorganic species during daytime, representing at least $50 \%$ of the total inorganic $\mathrm{Br}_{\mathrm{y}}$. For values of $\mathrm{O}_{3}=25 \mathrm{ppbv}$, the $\mathrm{Br} / \mathrm{Br}_{\mathrm{y}}$ and $\mathrm{HBr} / \mathrm{Br}_{\mathrm{y}}$ ratios display a slight sensitivity to total $\mathrm{NO}_{\mathrm{y}}$ (400 pptv), but $\mathrm{Br}$ and $\mathrm{BrO}$ remain the dominant daytime species for all values of $\mathrm{NO}_{\mathrm{y}}$ reported by Murphy et al. (1993) for the TTL. In regions with higher ozone abundances (i.e., > $100 \mathrm{ppbv}$ ), as in the lower stratosphere, the diurnal $\mathrm{Br}-\mathrm{BrO}$ steady state is displaced to favor the $\mathrm{BrO}$ production.

The sensitivity of the noontime $\mathrm{Br} / \mathrm{Br}_{\mathrm{y}}, \mathrm{BrO} / \mathrm{Br}_{\mathrm{y}}$, and $\mathrm{HBr} / \mathrm{Br}_{\mathrm{y}}$ ratios to temperature is shown in Fig. 9. For these calculations, $\mathrm{O}_{3}=25 \mathrm{ppbv}$ and $\mathrm{H}_{2} \mathrm{O}$ is set to its temperaturedependent saturation mixing ratio, although nearly identical results are found if $\mathrm{H}_{2} \mathrm{O}$ is kept constant at 12.5 ppmv. The simulations show that for temperatures less than $\sim 200 \mathrm{~K}$, atomic $\mathrm{Br}$ is expected to constitute at least half of total $\mathrm{Br}_{\mathrm{y}}$. Model results shown by the solid lines are for Run_la conditions. The temperature sensitivity is driven by the $\mathrm{Br}+\mathrm{O}_{3}$, $\mathrm{Br}+\mathrm{H}_{2} \mathrm{CO}, \mathrm{Br}+\mathrm{HO}_{2}$, and $\mathrm{BrO}+\mathrm{NO}$ rate constants, each of which acts to increase the $\mathrm{Br} / \mathrm{Br}_{\mathrm{y}}$ ratio and decrease the $\mathrm{HBr} / \mathrm{Br}_{\mathrm{y}}$ ratio, with decreasing temperature. The uncertainty in the calculated abundances of $\mathrm{Br}, \mathrm{BrO}$, and $\mathrm{HBr}$ due to gas phase and heterogeneous processes is shown by the dashed and dotted lines in Fig. 9a-c. For gas-phase processes, the uncertainty of individual kinetic parameters is based on JPL-2010 (Sander et al., 2011). The uncertainty due to heterogeneous processes considers cases Run_O and Run_2b (see Supplement). 

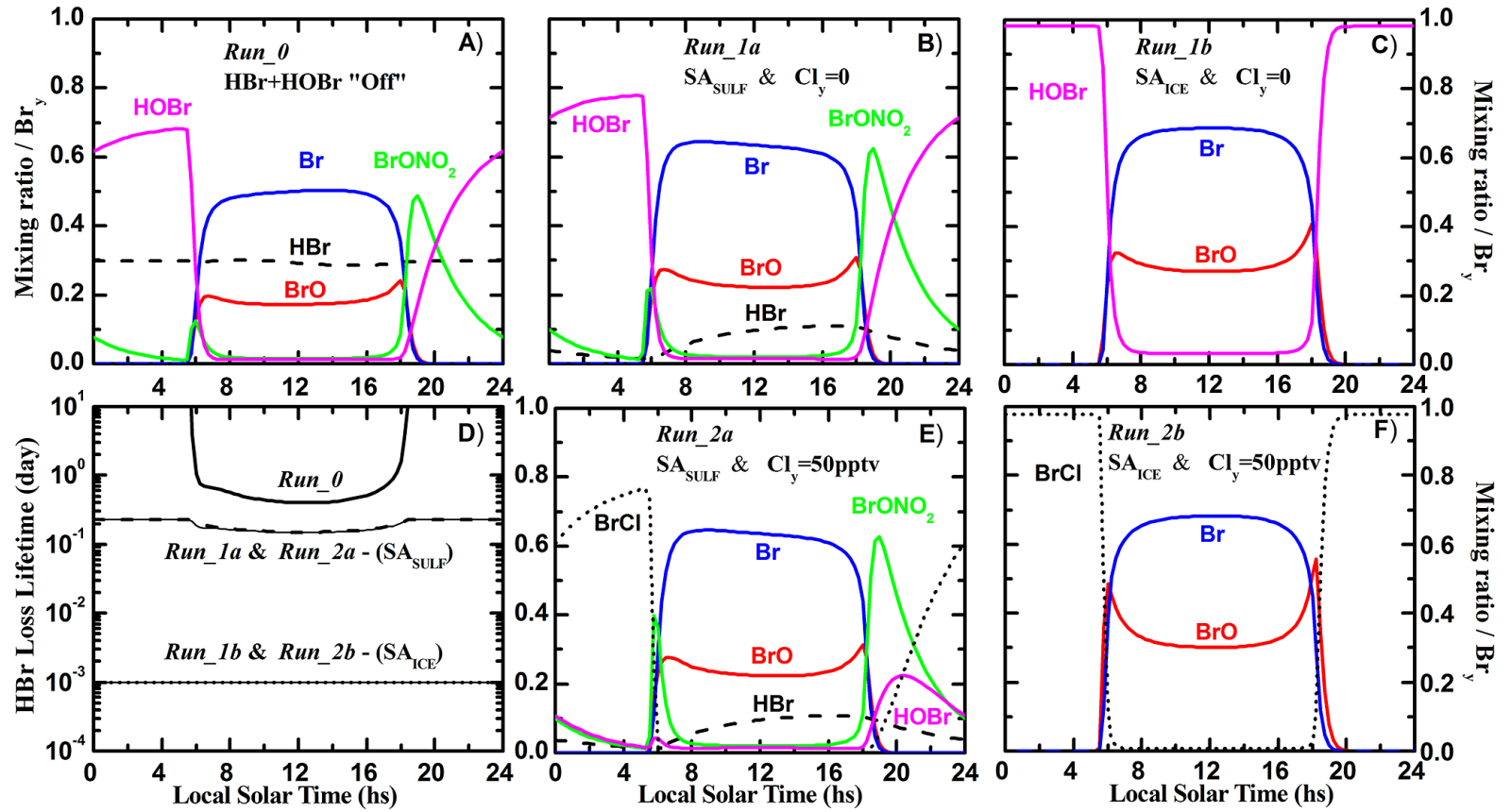

Figure 7. Calculated abundance of inorganic bromine species as a function of local solar time for different sensitivity simulations: (a) Run_O $\left(\mathrm{SA}_{\mathrm{SULF}} ; \gamma_{\mathrm{HOBr}}+\mathrm{HBr}=0 ; \mathrm{Cl}_{\mathrm{y}}=0\right) ;(\mathbf{b}) R u n \_1 a\left(\mathrm{SA}_{\mathrm{SULF}} ; \gamma_{\mathrm{HOBr}}+\mathrm{HBr}=0.25 ; \mathrm{Cl}_{\mathrm{y}}=0\right) ;(\mathbf{c}) R u n_{-} 1 b\left(\mathrm{SA} \mathrm{ICE} ; \gamma_{\mathrm{HOBr}}+\mathrm{HBr}=0.1\right.$; $\left.\mathrm{Cl}_{\mathrm{y}}=0\right)$; (d) photochemical lifetime of $\mathrm{HBr}$ for all five sensitivity simulations; (e) Run_2a $\left(\mathrm{SA}_{\mathrm{SULF}} ; \gamma_{\mathrm{HOBr}}+\mathrm{HBr}=0.25 ; \mathrm{Cl} \mathrm{y}_{\mathrm{y}}=50 \mathrm{pptv}\right)$; (f) Run_2b $\left(\mathrm{SA}\right.$ ICE $\left.; \gamma_{\mathrm{HOBr}}+\mathrm{HBr}=0.1 ; \mathrm{Cl}_{\mathrm{y}}=50 \mathrm{pptv}\right)$.

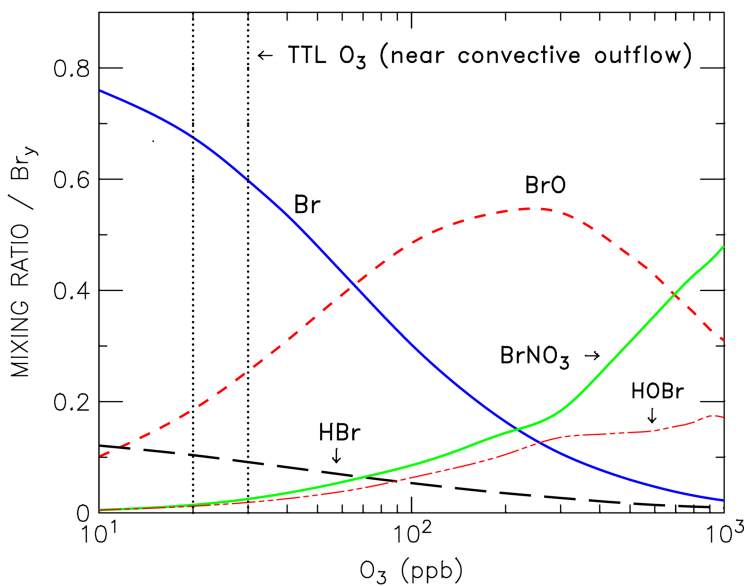

Figure 8. Box-model partitioning of $\mathrm{Br}_{\mathrm{y}}$ species as a function of ozone mixing ratio. The abundances (normalized to total $\mathrm{Br}_{\mathrm{y}}$ ) are from diurnal photochemical steady state conditions at local noon. Inputs for aerosol surface area, inorganic chlorine, and $\gamma_{\mathrm{HOBr}}+\mathrm{HBr}$ are for Run_la.

\subsection{Global model sensitivities to processes and sources}

Table 3 describes a set of five global sensitivity simulations that were performed with CAM-Chem to quantify the contribution of each source gas to the PGVSL and SGVSL bromine burden. Besides including the surface oceanic flux of only a unique VSL source gas or turning on/off the heterogeneous reactions, the rest of the parameterizations considered in the chemical scheme are identical to those used for the baseline simulation (cam_Full_Br). To avoid extraneous chemical perturbations related to differences in stratospheric halogen loading of bromine and chlorine, all simulations considered identical boundary conditions for long-lived halocarbon species (i.e., $\mathrm{CFCs}, \mathrm{CH}_{3} \mathrm{Br}$ and halons).

Table 4 presents values of $\mathrm{PG}_{\mathrm{VSL}}$ and $\mathrm{SG}_{\mathrm{VSL}}$ as well as the total bromine loading due to VSL sources $\left(\sum \mathrm{Br}\right)$ for the lower TTL $(12 \mathrm{~km})$ and upper TTL $(17 \mathrm{~km})$, for various regions and averaging periods. Note that for the cam_NoVSL simulation, SGVSL includes the contribution of all long-lived bromocarbons, while the $\mathrm{PG}_{\mathrm{VSL}}$ portion represents the $\mathrm{Br}_{\mathrm{y}}$ decomposition products released by photolysis of $\mathrm{CH}_{3} \mathrm{Br}$ below the tropopause. Table 4 also presents the $R$ quotient for each CAM-Chem sensitivity simulation, computed as

$R=\frac{\mathrm{PG}_{\mathrm{VSL}}}{\mathrm{SG}_{\mathrm{VSL}}}$.

As CAM-Chem includes a complete treatment of halogen chemistry within the troposphere, the term PGVSL in the numerator is the sum of (i) the decomposition products from the $\mathrm{SG}_{V S L}$ entering the lower TTL, (ii) and the vertical transport of $\mathrm{Br}_{\mathrm{y}}$ reaching the lower TTL from the FT and MBL. For the cam_CHBr3, cam_CH2Br2 and cam_MinorVSL runs, $\mathrm{PG}_{\text {cam_NoVSL }}$ is subtracted from the numerator to account 

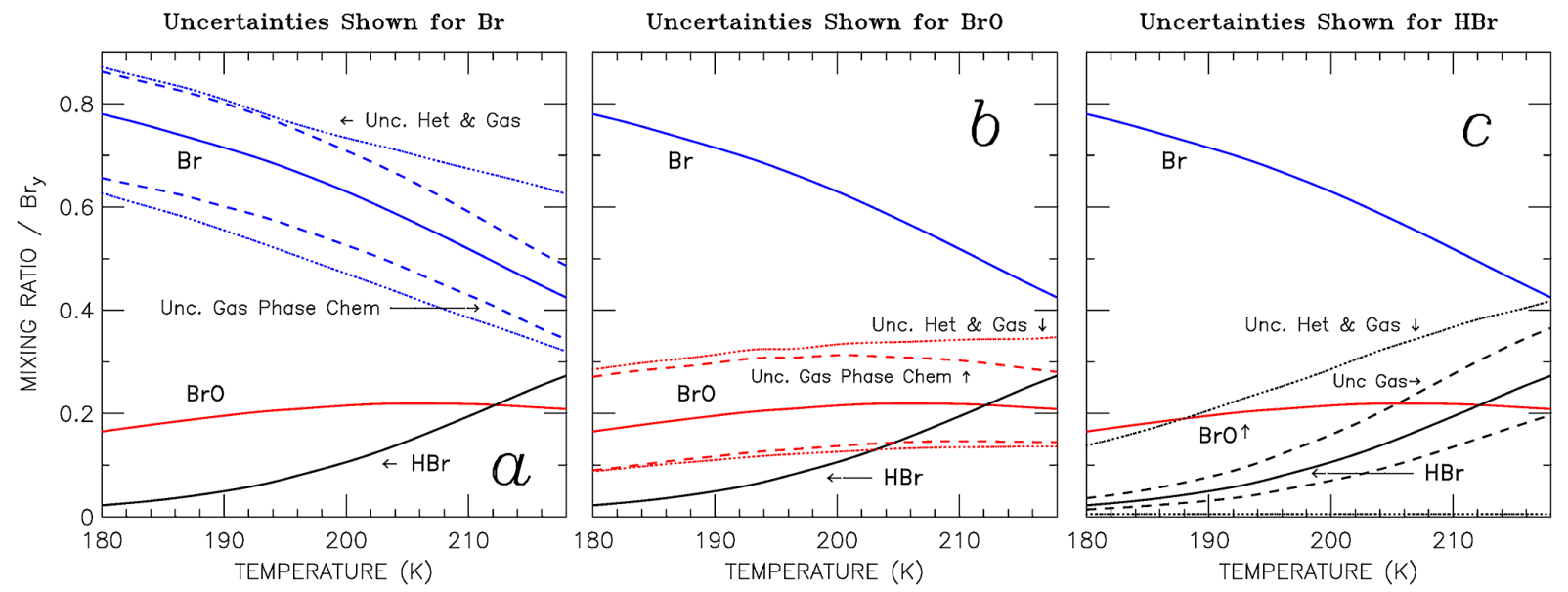

Figure 9. Temperature dependence of the calculated abundance of atomic $\mathrm{Br}, \mathrm{BrO}$ and $\mathrm{HBr}$ at local noon. The baseline simulation (solid line) assumes conditions for $\mathrm{SA}, \mathrm{Cl}_{\mathrm{y}}$, and $\gamma_{\mathrm{HOBr}}+\mathrm{HBr}$ from Run_la: (a) atomic $\mathrm{Br}$ uncertainties considering only gas-phase processes (dashed lines) and combined uncertainty considering both heterogeneous and gas-phase processes (dotted lines). Uncertainties for $\mathrm{BrO}$ and $\mathrm{HBr}$ are shown in panels (b) and (c), respectively.

for stratospheric injection of product gases resulting from tropospheric degradation of $\mathrm{CH}_{3} \mathrm{Br}$ below the coldest point tropopause. Several global modeling studies oriented to determine the magnitude of the stratospheric bromine injection due to VSL do not consider a detailed treatment of the tropospheric halogen chemistry, and then approximate the entrainment of $\mathrm{Br}_{\mathrm{y}}$ from the lower troposphere.

CAM-Chem sensitivities indicate that on an annual average, the $\mathrm{Br}_{\mathrm{y}}$ abundance in the upper TTL can be of up to one order of magnitude greater than $\mathrm{SG}_{\mathrm{VSL}}$ if only $\mathrm{CHBr}_{3}$ sources are considered $(R \sim 8)$. In comparison, when only $\mathrm{CH}_{2} \mathrm{Br}_{2}$ is taken into account, $R \sim 0.2$ due to the greater photochemical lifetime of this source (see Table 4) and only 0.3 pptv of bromine is released from the SGVSL to the inorganic portion below the tropopause (see Table 4). During convective events, the photodegradation of bromocarbons within the TTL account only for a small portion of the $\mathrm{Br}_{\mathrm{y}}$ loading: between 12 and $17 \mathrm{~km}$, the $\mathrm{SG}_{\mathrm{VSL}}$ reduction is $\sim 0.06,0.1$ and 1.0 pptv for cam_MinorVSL, cam_CH2Br2 and $\mathrm{Cam}_{-} \mathrm{CHBr} 3$, respectively. This highlights the importance of considering the different dynamical timescales of large-scale ascent and deep convective events, as well as a detailed tropospheric chemical mechanism, when computing the partitioning between SGVSL and PGVSL of short-lived species.

The entrainment of $\mathrm{Br}_{\mathrm{y}}$ into the TTL from the lower troposphere constitutes an important portion $(\sim 1.0 \mathrm{pptv}$ when all VSL sources are considered for the tropical annual average) of the PGVSL component to stratospheric injection (see Table 4). Photodegradation of $\mathrm{CHBr}_{3}$ represents $\sim 90 \%$ of the annual PGVSL reaching the lower TTL even when heterogeneous recycling on sea-salt aerosol is not considered. Indeed, integrated in the tropics SSLT recycling can account, at most, for about $10 \%$ of the $\mathrm{Br}_{\mathrm{y}}$ levels at $12 \mathrm{~km}$, and only $3 \%$ of the total $\mathrm{PG}_{\mathrm{VSL}}$ at $17 \mathrm{~km}$. The situation changes considerably during events of vigorous convection within the WP region. There, the $\mathrm{Br}_{\mathrm{y}}$ loading at the lower TTL is significantly reduced from $3.6 \mathrm{pptv}$ for cam_Full_Br to $0.5 \mathrm{pptv}$ for cam_NoSSLT. Then, in strong convective regions the $\mathrm{Br}_{\mathrm{y}}$ loading in the TTL is dominated by the entrainment of product gases from the FT and MBL instead of being controlled by VSL degradation (see below).

\subsubsection{Implications of heterogeneous recycling reactions on the composition of the TTL}

Figure 10 shows vertical profiles for the main variables affecting the heterogeneous rates for Reactions (R1) $(\mathrm{HBr}+\mathrm{HOBr})$ and $(\mathrm{R} 2)(\mathrm{HCl}+\mathrm{HOBr})$ considering the baseline cam_Full_Br simulation. The vertical variation of the surface area density of ice particles $\left(\mathrm{SA} \mathrm{ICE}_{\mathrm{IC}}\right)$, liquid droplets $\left(\mathrm{SA}_{\mathrm{LIQ}}\right)$, stratospheric sulfate aerosols $\left(\mathrm{SA}_{\mathrm{SULF}}\right)$ and sea-salt aerosols (SASSLT) between $20^{\circ} \mathrm{N}$ and $20^{\circ} \mathrm{S}$ is presented in Fig. 10a. Within the TTL, SAICE densities are at least 1 order of magnitude greater than those for SASULF, therefore ice-mediated heterogeneous reactions are expected to predominate within the TTL in agreement with other modeling studies (Aschmann and Sinnhuber, 2013). The SAICE density for the tropical annual average (solid lines) can be up to a factor of 10 smaller than for the WP region during February (dashed lines). This indicates that in regions of strong convection the efficiency of heterogeneous reactions within the TTL can be considerably enhanced. Indeed, the rapid uplift of air-masses and the colder temperatures increase the total amount of ice-cloud droplets where heterogeneous reactions occur (Williams et al., 2009).

Our box-model sensitivities indicate that the other important factor controlling the efficiency of heterogeneous recy- 
Table 3. Description of the CAM-Chem setup used for different global sensitivity simulations.

\begin{tabular}{ll}
\hline Simulation name & Description \\
\hline cam_Full_Br & Considers all $\mathrm{SG}_{\mathrm{VSL}}$ and long-lived (LL) sources \\
cam_NoVSL & Considers only LL sources and no SGVSL \\
cam_CHBr3 & Considers only $\mathrm{CHBr}$ and $\mathrm{LL}$ sources \\
cam_CH2Br2 & Considers only $\mathrm{CH}_{2} \mathrm{Br}_{2}$ and LL sources \\
cam_MinorVSL & Considers $\mathrm{CH}_{2} \mathrm{BrCl}_{\mathbf{C}} \mathrm{CHBr} 2 \mathrm{Cl}, \mathrm{CHBrCl}{ }_{2}, \mathrm{CH}_{2} \mathrm{IBr}$ and LL sources \\
cam_NoSSLT & Same sources as cam_Full_Br. Recycling reactions over sea-salt aerosols had been turned off* \\
\hline
\end{tabular}

* Heterogeneous reactions HSS0-HSS5 of Table S1 have not been considered.

Table 4. Partitioning of SGVSL and PGVSL species within the TTL for different CAM-Chem simulations.

\begin{tabular}{|c|c|c|c|c|c|c|c|c|c|c|c|c|}
\hline Region (period) & \multicolumn{4}{|c|}{ Tropical average (annual) ${ }^{b}$} & \multicolumn{4}{|c|}{ Western Pacific (February) ${ }^{\mathrm{c}}$} & \multicolumn{4}{|c|}{ Vigorous event (3 days) ${ }^{\mathrm{d}}$} \\
\hline \multirow[t]{2}{*}{ Sensitivity } & \multicolumn{4}{|c|}{ Upper TTL (17 km) } & \multicolumn{4}{|c|}{ Upper TTL (17 km) } & \multicolumn{4}{|c|}{ Upper TTL (17 km) } \\
\hline & $\mathrm{PG}_{\mathrm{VSL}}$ & $\mathrm{SG}_{\mathrm{VSL}}$ & $\sum \mathrm{Br}$ & $R$ & $\mathrm{PG}_{\mathrm{VSL}}$ & $\mathrm{SG}_{\mathrm{VSL}}$ & $\sum \mathrm{Br}$ & $R^{\mathrm{d}}$ & $\mathrm{PG}_{\mathrm{VSL}}$ & $\mathrm{SG}_{\mathrm{VSL}}$ & $\sum \mathrm{Br}$ & $R$ \\
\hline cam_Full_Br & 3.0 & 2.0 & 5.0 & 1.5 & 3.86 & 3.86 & 7.7 & 1.0 & 3.0 & 4.6 & 7.6 & 0.6 \\
\hline cam_NoVSL $L^{\mathrm{a}}$ & 0.8 & 15.5 & 16.4 & 0.05 & 0.4 & 16.3 & 16.8 & 0.03 & 0.3 & 16.3 & 16.6 & 0.02 \\
\hline cam_CHBr3 & 2.5 & 0.2 & 2.7 & 8.0 & 3.1 & 1.3 & 4.4 & 2.0 & 2.5 & 2.0 & 4.5 & 1.1 \\
\hline $\mathrm{cam}_{-} \mathrm{CH} 2 \mathrm{Br} 2$ & 1.1 & 1.5 & 2.6 & 0.2 & 0.7 & 1.9 & 2.6 & 0.1 & 0.5 & 1.9 & 2.4 & 0.1 \\
\hline cam_MinorVSL & 1.1 & 0.3 & 1.5 & 0.9 & 2.1 & 0.6 & 2.7 & 2.7 & 1.8 & 0.7 & 2.5 & 2.3 \\
\hline \multirow[t]{3}{*}{ cam_NoSSLT } & 2.9 & 2.0 & 4.9 & 1.4 & 1.8 & 3.8 & 5.6 & 0.5 & 0.8 & 4.6 & 5.4 & 0.2 \\
\hline & \multicolumn{4}{|c|}{ Lower TTL (12 km) } & \multicolumn{4}{|c|}{ Lower TTL (12 km) } & \multicolumn{4}{|c|}{ Lower TTL (12 km) } \\
\hline & $\mathrm{PG}_{\mathrm{VSL}}$ & $\mathrm{SG}_{\mathrm{VSL}}$ & $\sum \mathrm{Br}$ & $R$ & $\mathrm{PG}_{\mathrm{VSL}}$ & $\mathrm{SG}_{\mathrm{VSL}}$ & $\sum \mathrm{Br}$ & $R$ & $\mathrm{PG}_{\mathrm{VSL}}$ & $\mathrm{SG}_{\mathrm{VSL}}$ & $\sum \mathrm{Br}$ & $R$ \\
\hline cam_Full_Br & 1.0 & 4.3 & 5.3 & 0.2 & 2.5 & 5.1 & 7.5 & 0.5 & 3.6 & 5.7 & 9.3 & 0.6 \\
\hline cam_NoVSL $L^{\mathrm{a}}$ & 0.1 & 16.3 & 16.4 & 0.003 & 0.4 & 16.4 & 16.8 & 0.02 & 0.3 & 16.5 & 16.8 & 0.02 \\
\hline cam_CHBr3 & 0.9 & 1.9 & 2.8 & 0.4 & 2.1 & 2.4 & 4.5 & 0.7 & 2.3 & 3.0 & 5.3 & 0.6 \\
\hline $\mathrm{Cam}_{-} \mathrm{CH} 2 \mathrm{Br} 2$ & 0.1 & 1.8 & 1.9 & 0.0 & 0.6 & 2.0 & 2.6 & 0.1 & 0.6 & 2.0 & 2.6 & 0.1 \\
\hline cam_MinorVSL & 0.2 & 0.6 & 0.8 & 0.2 & 1.4 & 0.7 & 2.1 & 1.5 & 3.0 & 0.7 & 3.7 & 3.7 \\
\hline cam_NoSSLT & 0.9 & 4.3 & 5.1 & 0.2 & 0.9 & 5.0 & 5.9 & 0.2 & 0.5 & 5.7 & 6.1 & 0.1 \\
\hline
\end{tabular}

cling of $\mathrm{HBr}$ and $\mathrm{HOBr}$ is the total amount of inorganic chlorine available as $\mathrm{HCl}$. Figure $10 \mathrm{~b}$ shows the vertical profile abundance of $\mathrm{HCl}$ and $\mathrm{Cl}_{\mathrm{y}}$ for the tropical annual average and the WP region during February. Chlorine levels of up to 50 pptv on an annual average are modeled within the tropics in agreement with previous reports (Marcy et al., 2004; Mébarki et al., 2010), although WP abundances remain below 10 pptv within the TTL, due to the faster vertical transport of VSL-chlorocarbons that decreases the release of chlorine atoms.

In the absence of solar radiation, $\mathrm{BrCl}$ is the dominant bromine nocturnal reservoir at $17 \mathrm{~km}$ within the WP region (see Fig. 11), indicating that the current implementation of heterogeneous recycling in CAM-Chem is more sensitive to the increase in $\mathrm{SA}_{\mathrm{ICE}}$ than to the decrease in $\mathrm{Cl}_{\mathrm{y}}$ levels within the high convective regions. Note in Fig. 10c that the efficiency of Reactions (R1) and (R2) within the TTL is at least 1 order of magnitude greater for the reactions occurring over $\mathrm{SA}_{\mathrm{ICE}}$ than over $\mathrm{SA}_{\mathrm{SULF}}$, being the latter the dominant substrate for recycling only above $20 \mathrm{~km}$. As the reaction rate for $\mathrm{HCl}$ recycling surpasses that for $\mathrm{HBr}$ recycling, and the $\mathrm{HCl}$ abundance rapidly increases towards the upper TTL and above (Mébarki et al., 2010), $\mathrm{BrCl}$ shows a pronounced nighttime peak at $\sim 17 \mathrm{~km}$ that rapidly decreases following the $\mathrm{SA}_{\text {ICE }}$ profile. Note that there still are very large uncertainties on both the vertical and geographical representation of SA ICE fields in chemical climate models (Williams et al., 2009; Aschmann and Sinnhuber, 2013) and the reactive uptake efficiencies of heterogeneous processes for halogen species (Crowley et al., 2010; Ammann et al., 2013). Hence, field measurements of $\mathrm{BrCl}, \mathrm{HOBr}$ and other bromine nighttime reservoirs, as well as laboratory measurements of $\mathrm{SA}_{\text {ICE }}$ reactions, would shed some light in the understanding of these fundamental processes. 


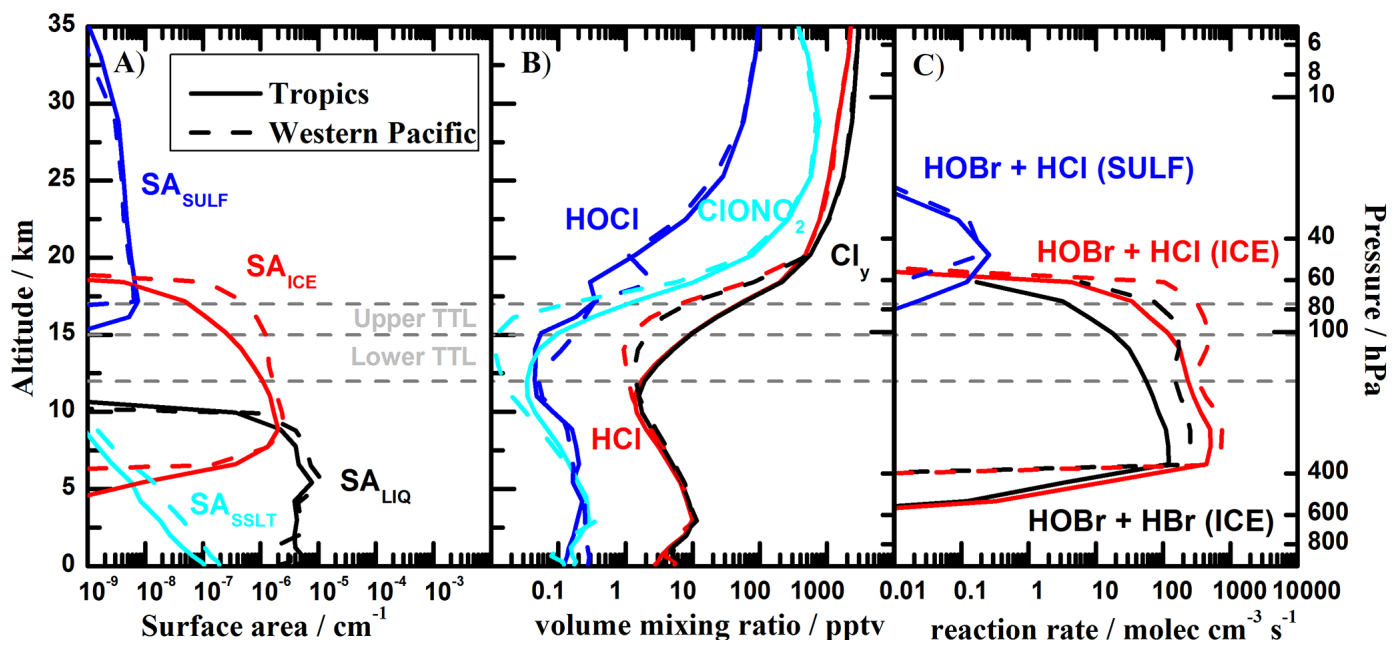

Figure 10. Vertical variation of CAM-Chem atmospheric constituents affecting the rate of heterogeneous reactions within the tropics (solid lines) and WP region (dotted lines): (a) $\mathrm{SA}_{\mathrm{ICE}}, \mathrm{SA}_{\mathrm{LIQ}}, \mathrm{SA}_{\mathrm{SULF}}$ and $\mathrm{SA}_{\mathrm{SSLT}}$; (b) average vertical profiles of $\mathrm{HCl}, \mathrm{HOCl}_{1} \mathrm{ClONO}_{2}$ and total inorganic chlorine $\left(\mathrm{Cl}_{\mathrm{y}}\right)$; (c) heterogeneous reaction rates over different types of surfaces.

\subsubsection{Impact of convective transport on the bromine burden and partitioning}

Figure 11 shows the distribution of the noon and midnight inorganic and organic vertical profile partitioning within the tropical WP during February, in a manner equivalent to Fig. 1, which showed equivalent model results for an annual average of the entire tropics. Several aspects of the sources and processes controlling the bromine partitioning in the TTL are evident comparing Figs. 1 and 11. First, there is a clear predominance of atomic $\mathrm{Br}$ as the most abundant $\mathrm{Br}_{\mathrm{y}}$ species during daytime, which corresponds to a localized enhancement of the bromine atoms forming the inhomogeneous tropical ring, as well as a marked increase in the $\mathrm{Br} / \mathrm{BrO}$ ratio in the WP (see Fig. 4). Second, $\mathrm{BrCl}$ becomes the most abundant bromine species at midnight, in agreement with the box-model sensitivity studies performed for the Run_2a and Run_2b cases (see also Fig. 10c). The role of heterogeneous recycling in the TTL highlights the importance of reducing the uncertainties related to the efficiency and temperature dependence of these reactions, and their competition relative to complete washout or ice removal from the atmosphere (Sinnhuber and Folkins, 2006; Aschmann and Sinnhuber, 2013). Third, both the organic and inorganic bromine burden of the TTL are enhanced within this region. Then, within the WP region during strong convection periods, the ratio $\mathrm{Br} / \mathrm{BrO}>1$ throughout the TTL, and atomic $\mathrm{Br}$ represents up to $60 \%$ of total $\mathrm{Br}_{\mathrm{y}}$. It is worth noting that for the cam_Full_Br scheme, the total bromine (i.e., $\mathrm{SG}_{\mathrm{VSL}}+\mathrm{PG}_{\mathrm{VSL}}$ ) loading in the upper TTL is slightly larger than in the lower TTL (see Table 4). This increase for the monthly average can be attributed to different local transport pathways within our definition of the WP region $\left(0^{\circ}<\mathrm{Lat}<20^{\circ} \mathrm{N}\right.$ and $\left.120^{\circ} \mathrm{E}<\mathrm{Lon}<165^{\circ} \mathrm{E}\right)$ : (i) trans- port from other latitudes and longitudes outside the defined WP; and (ii) intrusion events or subsidence from the $\mathrm{Br}_{\mathrm{y}}$-rich stratosphere.

Our results show that in the MBL and lower troposphere of the WP region, the total $\mathrm{Br}_{\mathrm{y}}$ abundance is up to a factor of 3 larger relative to the abundance modeled for the entire tropics (Figs. 1c, 11c). This substantial change can be attributed to the larger occurrence of sea-salt recycling reactions in coastal regions with strong convection, and their rapid vertical transport to the TTL: cam_NoSSLT sensitivity indicates that total $\mathrm{PG}_{\mathrm{VSL}}$ in the MBL is reduced by $\sim 7.5 \mathrm{pptv}$ when sea-salt reactions are turned off, decreasing the inorganic bromine reaching the coldest point tropopause by $\sim 2.2$ pptv. This uncertainty to $\mathrm{Br}_{\mathrm{y}}$ loading in the TTL due to SSLT recycling is of similar magnitude to the uncertainties recently found by Liang et al. (2014) due to changes in convection strength $(\sim 2.6 \mathrm{pptv})$, although they modeled a reduction in stratospheric bromine injection for their maximum convection conditions. It is worth noting that Liang et al. (2014) did not consider heterogeneous reactions for $\mathrm{HBr}$ nor $\mathrm{HOBr}$, and compared different sensitivities where not only the initiation and relaxation of convection was altered, but also the evaporation of rain and cloud formation was modified, i.e., the washout efficiency between sensitivities was changed. In contrast, all of the CAM-Chem sensitivities considered identical removal schemes and parameterizations, and we have focused on addressing the changes in $\mathrm{Br}_{\mathrm{y}}$ loading when we shift from the dominant large-scale ascent (tropical annual average) to the periods and regions where strong convective events are frequent (tropical Western Pacific). 


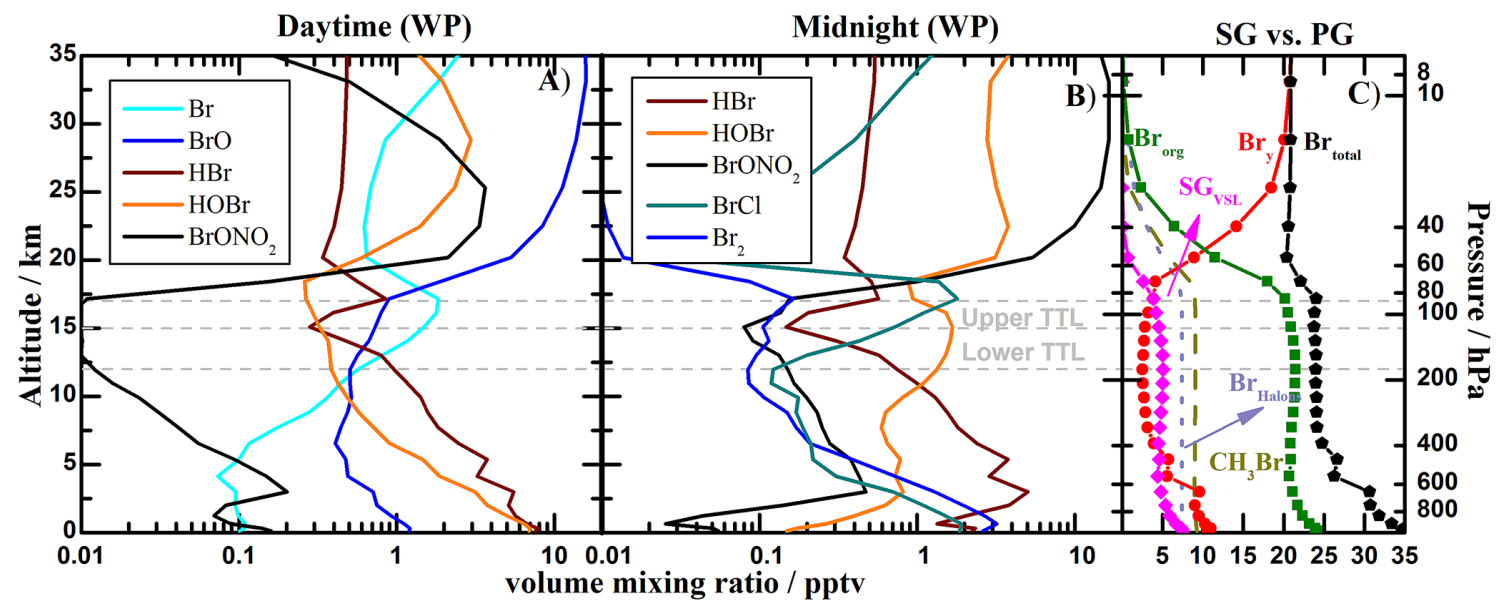

Figure 11. Vertical profile abundances of organic and inorganic bromine species within the WP region during February: (a) main Br $\mathrm{r}_{\mathrm{y}}$ species at noon; (b) main $\mathrm{Br}_{\mathrm{y}}$ species at midnight; and (c) $24 \mathrm{~h}$ average contribution of organic and inorganic species to total bromine.

\subsection{Implications for stratospheric injection and atmospheric ozone}

Our simulations suggest that the proportion of inorganic $\mathrm{Br}$ input to the stratosphere is higher $\left(\mathrm{PG}_{\mathrm{VSL}} \approx 3 \mathrm{pptv}\right)$ than the contribution from the carbon-bonded portion $\left(\mathrm{SG}_{\mathrm{VSL}} \approx\right.$ 2 pptv), resulting in a total stratospheric bromine injection of $\sim 5$ pptv. Tropospheric degradation of the long-lived bromine species $\mathrm{CH}_{3} \mathrm{Br}$ makes an important contribution, $0.7 \mathrm{pptv}$, to the total amount of inorganic bromine ( $\mathrm{PG}_{\mathrm{VSL}} \approx 3 \mathrm{pptv}$ ) that is transported across the tropopause (see Table 4). $\mathrm{CH}_{3} \mathrm{Br}$ is not commonly considered to be a VSL compound because its atmospheric removal lifetime of $\sim 9.6$ months is slightly longer than the 6-month cutoff used to denote very shortlived species (Montzka et al., 2011). However, we consider stratospheric injection of $\mathrm{Br}_{\mathrm{y}}$ compounds produced following the tropospheric decomposition of $\mathrm{CH}_{3} \mathrm{Br}$ to be part of $\mathrm{PG}_{V S L}$ because the ozone destruction potential of bromine in the lowermost stratosphere (LMS) depends critically on the amount of active bromine above the tropopause, regardless of origin (Salawitch et al., 2005). This highlights the need for climate models to incorporate a complete treatment of tropospheric bromine chemistry that includes both VSL and long-lived bromocarbons.

Our global simulations reveal distinctive features in the partitioning of SGVSL and PGVSL between air masses injected into the stratosphere within the WP region and the average tropics (see Figs. 1 and 11, and Table 4). First, VSL bromocarbons are produced at a remarkable rate by ocean biology within the WP, primarily in shallow coastal waters, and are subsequently transported by strong convection to the TTL. As expected, the faster the air masses are transported, the smaller the photolytic release of atomic bromine from VSL bromocarbons and the stronger the injection of the organic SGVSL fraction (Figs. 2b, 11c). Second, the greater SASSLT existent in the WP region compared to the aver- age tropics (Fig. 10a) enhances the sea-salt aerosol recycling flux of $\mathrm{Br}_{2}$ and $\mathrm{BrCl}$. The resulting $\mathrm{Br}_{\mathrm{y}}$ abundances within the MBL of the Western Pacific show a $\sim 3$-fold increase for the cam_Full_Br scheme $\left(\mathrm{Br}_{\mathrm{y}}^{\text {Tropics }} \approx 3.3 \mathrm{pptv}\right.$ and $\left.\mathrm{Br}_{\mathrm{y}}^{\mathrm{WP}} \approx 10.6 \mathrm{pptv}\right)$, mostly due to the recycling of bromine released from the shortest lived of all the VSL species considered $\left(\mathrm{CH}_{2} \mathrm{IBr}\right)$. Third, the rapid transport of $\mathrm{Br}_{\mathrm{y}}$-rich air masses from the MBL to the lower TTL reduces the wet deposition of $\mathrm{PG}_{\mathrm{VSL}}$ species, additionally increasing the $\mathrm{Br}_{\mathrm{y}}$ abundance in the WP TTL. This results in a local enhancement of the total bromine loading at $\theta_{\mathrm{CPT}}$ of $7.7 \mathrm{pptv}$ for the WP region during February (with both $\mathrm{SG}_{\mathrm{VSL}}$ and $\mathrm{PG}_{\mathrm{VSL}}$ coincidentally reaching $3.85 \mathrm{pptv}$ ) compared to the annual average injection of $5 \mathrm{pptv}$. Fourth, during the fast uplifting event that results in the $\mathrm{Br} / \mathrm{BrO}$ peak shown in Fig. 4, the SGVSL (4.6 pptv) > PGVSL (3.0 pptv) suggests that the tropical ring of atomic bromine exists even when $R<1$. Finally, note that in the case of the tropical annual average the $\mathrm{Br}_{\mathrm{y}}$ loading in the TTL is controlled by $\mathrm{SG}_{\mathrm{VSL}}$ decomposition (mostly $\mathrm{CHBr}_{3}$, Fig. 2a) and the sea-salt contribution represents $<3 \%$ of the $\mathrm{PG}_{\mathrm{VSL}}$ reaching the upper TTL. Then, the additional inorganic source released from sea salt only impacts the stratospheric bromine injection within strong convective regions; while due to the longer timescales of the dominant large-scale ascent, sea-salt recycling reactions do not affect the average tropical $\mathrm{PG}_{\mathrm{VSL}}$ injection on the global scale.

\section{Summary and conclusions}

Our estimate of the stratospheric injection of bromine compounds, naturally emitted from the oceans, suggests that the inorganic bromine injected into the stratosphere is larger ( $\sim 3$ pptv) than that from carbon-bonded very shortlived species $(\sim 2 \mathrm{pptv})$. Then, accounting for the contri- 
butions from all VSL bromocarbons, an overall quotient $R=\mathrm{PG}_{V S L} / \mathrm{SG}_{V S L}$ of $\sim 1.5$ (dominated by the $\mathrm{CHBr}_{3}$ partitioning) is obtained. This result differs from previous model studies that reported that the SGVSL injection is the dominant contribution (Hossaini et al., 2012; Aschmann and Sinnhuber, 2013), or that $\mathrm{SG}_{\mathrm{VSL}}$ and $\mathrm{PG}_{\mathrm{VSL}}$ contributions are equivalent (Liang et al., 2010), although those reports considered either constant surface mixing ratios of VSL bromocarbons or a simplified representation of inorganic bromine chemistry and removal processes.

The current CAM-Chem scheme includes geographically and seasonally varying VSL emissions as well as a detailed representation of the multiphase photochemistry from the ocean surface to the middle stratosphere. Then, our model captures regions where surface halocarbon fluxes are relatively large (i.e., coastal areas) and represents the rapid, deep convective updraft of these air masses to the lower TTL (i.e., WP region). The independent representation of removal processes for each species ( $\mathrm{HOBr}, \mathrm{HBr}, \mathrm{BrONO}_{2}$, etc.) allows for an improved consideration of the various deposition processes (i.e., scavenging in-cloud precipitation, below-cloud washout, large-scale removal and re-evaporation, etc.) that affect the upper atmosphere inorganic bromine loading. In addition, the consideration of sea-salt recycling reactions within the MBL and its convective transport allow us to account for an additional geographically varying natural source of $\mathrm{Br}_{\mathrm{y}}$ to the lower TTL.

As shown above, a substantial portion of the bromine supplied by VSL bromocarbons is available in active form before reaching the LMS. Low ozone and temperature conditions make bromine atoms the dominant inorganic species during the sunlit tropical upper troposphere, generating a natural ring of atomic bromine that circles the tropics with the sun. If confirmed by observation, the tropical ring of atomic bromine would be indicative of a direct supply of inorganic bromine to the LMS by biogenic VSL bromocarbons. The inorganic bromine injection into the LMS has the most important effect on stratospheric ozone during times of high sulfate aerosol loading after major volcanic eruptions (Salawitch et al., 2005), following the convection injection of water vapor (Anderson et al., 2012), or under proposed scenarios to artificially increase the stratospheric aerosol burden to mitigate climate change (Tilmes et al., 2012). Then, the supply of inorganic bromine from VSL would likely render the ozone layer more sensitive to future changes in ocean biogeochemistry than current predictions, since most chemistry-climate models presently neglect oceanic bromocarbon sources or detailed tropospheric bromine chemistry.

Heterogeneous reactions of $\mathrm{HBr}$ and $\mathrm{HOBr}$ are key uncertainties in quantifying the fate of inorganic products produced following the decomposition of biogenic bromocarbons. The fingerprint of heterogeneous reactions is revealed by the behavior of nighttime reservoirs and the abundance of daytime $\mathrm{HBr}$ and atomic $\mathrm{Br}$. Therefore, speciated measurements of atomic bromine during the day and nighttime
$\mathrm{BrCl}$ and/or $\mathrm{HOBr}$ in the TTL would provide insight into the nature of heterogeneous chemical processes, which are profoundly important because they potentially regulate the efficiency of $\mathrm{Br}_{\mathrm{y}}$ removal by particle sedimentation.

Our modeled contribution of VSL bromocarbons and their breakdown products to stratospheric $\mathrm{Br}_{y}$ represents an increment of $\sim 25 \%$ to the stratospheric bromine burden supplied by long-lived sources $\left(\mathrm{CH}_{3} \mathrm{Br}\right.$ and halons). This percentage will likely rise in the future as the atmospheric burden of long-lived sources declines due to a near cessation of anthropogenic emission. If the production and transport of VSL bromocarbons is found to be sensitive to climatically driven changes in the state of the world's oceans (atmospheric winds, sea surface temperature, upwelling, and/or nutrient supply), then the tropical $\mathrm{Br}$ ring represents a potentially important new link between climate change and atmospheric ozone. All of this highlights the importance of including a detailed description of the interaction between surface fluxes, convective transport and halogen photochemistry in chemistry-climate model simulations.

\section{The Supplement related to this article is available online at doi:10.5194/acp-14-13391-2014-supplement.}

Acknowledgements. This work was supported by the Consejo Superior de Investigaciones Científicas (CSIC), Spain. The National Center for Atmospheric Research (NCAR) is funded by the National Science Foundation (NSF). Computing resources (ark:/85065/d7wd3xhc) were provided by the Climate Simulation Laboratory at NCAR's Computational and Information Systems Laboratory (CISL), sponsored by the NSF. The CESM project (which includes CAM-Chem) is supported by the NSF and the Office of Science (BER) of the US Department of Energy. This work was also sponsored by the NASA Atmospheric Composition Modeling and Analysis Program Activities (ACMAP), grant/cooperative agreement number NNX11AH90G and NNX12AB10G as well as the NASA Modeling and Analysis Program grant NNH12ZDA001N. We gratefully appreciate the collaboration with Paul Wennberg, at an early stage of this research, who suggested $\mathrm{BrO}$ would titrate to $\mathrm{Br}$ under the low $\mathrm{O}_{3}$ conditions of the tropical troposphere. R. P. Fernandez would like to thank CONICET and UTN/UNCuyo for prorogating the designation as Assistant Researcher in Argentina in order to continue the postdoc position at CSIC, Spain. R. J. Salawitch appreciates the assistance of Pamela Wales for the implementation of JPL-2010 kinetics in the box-model simulations.

Edited by: G. Stiller 


\section{References}

Abbatt, J. P. D.: Heterogeneous reaction of $\mathrm{HOBr}$ with $\mathrm{HBr}$ and $\mathrm{HCl}$ on ice surfaces at $228 \mathrm{~K}$, Geophys. Res. Lett., 21, 665-668, doi:10.1029/94GL00775, 1994.

Abbatt, J. P. D., Thomas, J. L., Abrahamsson, K., Boxe, C., Granfors, A., Jones, A. E., King, M. D., Saiz-Lopez, A., Shepson, P. B., Sodeau, J., Toohey, D. W., Toubin, C., von Glasow, R., Wren, S. N., and Yang, X.: Halogen activation via interactions with environmental ice and snow in the polar lower troposphere and other regions, Atmos. Chem. Phys., 12, 6237-6271, doi:10.5194/acp-12-6237-2012, 2012.

Ammann, M., Cox, R. A., Crowley, J. N., Jenkin, M. E., Mellouki, A., Rossi, M. J., Troe, J., and Wallington, T. J.: Evaluated kinetic and photochemical data for atmospheric chemistry: Volume VI - heterogeneous reactions with liquid substrates, Atmos. Chem. Phys., 13, 8045-8228, doi:10.5194/acp-13-8045-2013, 2013.

Anderson, J. G., Wilmouth, D. M., Smith, J. B., and Sayres, D. S.: UV dosage levels in summer: increased risk of ozone loss from convectively injected water vapor, Science, 337, 835-839, doi:10.1126/science.1222978, 2012.

Aschmann, J. and Sinnhuber, B.-M.: Contribution of very shortlived substances to stratospheric bromine loading: uncertainties and constraints, Atmos. Chem. Phys., 13, 1203-1219, doi:10.5194/acp-13-1203-2013, 2013.

Aschmann, J., Sinnhuber, B.-M., Atlas, E. L., and Schauffler, S. M.: Modeling the transport of very short-lived substances into the tropical upper troposphere and lower stratosphere, Atmos. Chem. Phys., 9, 9237-9247, doi:10.5194/acp-9-9237-2009, 2009.

Aschmann, J., Sinnhuber, B.-M., Chipperfield, M. P., and Hossaini, R.: Impact of deep convection and dehydration on bromine loading in the upper troposphere and lower stratosphere, Atmos. Chem. Phys., 11, 2671-2687, doi:10.5194/acp-11-2671-2011, 2011.

Ashfold, M. J., Harris, N. R. P., Atlas, E. L., Manning, A. J., and Pyle, J. A.: Transport of short-lived species into the Tropical Tropopause Layer, Atmos. Chem. Phys., 12, 6309-6322, doi:10.5194/acp-12-6309-2012, 2012.

Atkinson, R., Baulch, D. L., Cox, R. A., Crowley, J. N., Hampson, R. F., Hynes, R. G., Jenkin, M. E., Rossi, M. J., and Troe, J.: Evaluated kinetic and photochemical data for atmospheric chemistry: Volume III - gas phase reactions of inorganic halogens, Atmos. Chem. Phys., 7, 981-1191, doi:10.5194/acp-7-981-2007, 2007.

Atkinson, R., Baulch, D. L., Cox, R. A., Crowley, J. N., Hampson, R. F., Hynes, R. G., Jenkin, M. E., Rossi, M. J., Troe, J., and Wallington, T. J.: Evaluated kinetic and photochemical data for atmospheric chemistry: Volume IV - gas phase reactions of organic halogen species, Atmos. Chem. Phys., 8, 4141-4496, doi:10.5194/acp-8-4141-2008, 2008.

ATTREX: Airborne Tropical Tropopause Experiment Project, Funded by NASA, available at: https://espo.nasa.gov/missions/ attrex (last access: 18 December 2013), 2014.

Bergman, J. W., Jensen, E. J., Pfister, L., and Yang, Q.: Seasonal differences of vertical-transport efficiency in the tropical tropopause layer: On the interplay between tropical deep convection, largescale vertical ascent, and horizontal circulations, J. Geophys. Res., 117, D05302, doi:10.1029/2011JD016992, 2012.

Brinckmann, S., Engel, A., Bönisch, H., Quack, B., and Atlas, E.: Short-lived brominated hydrocarbons - observations in the source regions and the tropical tropopause layer, Atmos. Chem. Phys., 12, 1213-1228, doi:10.5194/acp-12-1213-2012, 2012.

Carpenter, L. J. and Liss, P. S.: On temperate sources of bromoform and other reactive organic bromine gases, J. Geophys. Res., 105, 20539-20547, doi:10.1029/2000JD900242, 2000.

CAST: Coordinated Airborne Studies in the Tropics Project, Facil. Airborne Atmos. Meas., available at: http://www.faam.ac.uk/index.php/current-future-campaigns/ 384-cast-2014-co-ordinated-airborne-studies-in-the-tropics (last access: 18 December 2013), 2014.

CONTRAST: CONvective TRansport of Active Species in the Tropics Project Earth Observing Laboratory, Funded by NCAR UCAR NSF, available at: https://www.eol.ucar.edu/field_ projects/contrast (last access: 18 December 2013), 2014.

Crowley, J. N., Ammann, M., Cox, R. A., Hynes, R. G., Jenkin, M. E., Mellouki, A., Rossi, M. J., Troe, J., and Wallington, T. J.: Evaluated kinetic and photochemical data for atmospheric chemistry: Volume V - heterogeneous reactions on solid substrates, Atmos. Chem. Phys., 10, 9059-9223, doi:10.5194/acp-10-90592010, 2010.

Dorf, M., Butler, J. H., Butz, A., Camy-Peyret, C., Chipperfield, M. P., Kritten, L., Montzka, S. A., Simmes, B., Weidner, F., and Pfeilsticker, K.: Long-term observations of stratospheric bromine reveal slow down in growth, Geophys. Res. Lett., 33, L24803, doi:10.1029/2006GL027714, 2006.

Dorf, M., Butz, A., Camy-Peyret, C., Chipperfield, M. P., Kritten, L., and Pfeilsticker, K.: Bromine in the tropical troposphere and stratosphere as derived from balloon-borne $\mathrm{BrO}$ observations, Atmos. Chem. Phys., 8, 7265-7271, doi:10.5194/acp-8-72652008, 2008.

Emmons, L. K., Walters, S., Hess, P. G., Lamarque, J.-F., Pfister, G. G., Fillmore, D., Granier, C., Guenther, A., Kinnison, D., Laepple, T., Orlando, J., Tie, X., Tyndall, G., Wiedinmyer, C., Baughcum, S. L., and Kloster, S.: Description and evaluation of the Model for Ozone and Related chemical Tracers, version 4 (MOZART-4), Geosci. Model Dev., 3, 43-67, doi:10.5194/gmd3-43-2010, 2010.

Folkins, I. and Braun, C.: Tropical ozone as an indicator of deep convection, J. Geophys. Res., 107, 4184, doi:10.1029/2001JD001178, 2002.

Fueglistaler, S., Dessler, A. E., Dunkerton, T. J., Folkins, I., Fu, Q., and Mote, P. W.: Tropical tropopause layer, Rev. Geophys., 47, 1-31, doi:10.1029/2008RG000267, 2009.

Fuhlbrügge, S., Krüger, K., Quack, B., Atlas, E., Hepach, H., and Ziska, F.: Impact of the marine atmospheric boundary layer conditions on VSLS abundances in the eastern tropical and subtropical North Atlantic Ocean, Atmos. Chem. Phys., 13, 6345-6357, doi:10.5194/acp-13-6345-2013, 2013.

Gettelman, A. and Forster, P. M. D. F.: A Climatology of the Tropical Tropopause Layer., J. Meteorol. Soc. Japan, 80, 911-924, doi:10.2151/jmsj.80.911, 2002.

Hanson, D. R., Ravishankara, A. R., and Solomon, S.: Heterogeneous reactions in sulfuric acid aerosols: A framework for model calculations, J. Geophys. Res., 99, 3615, doi:10.1029/93JD02932, 1994.

Holmes, C. D., Jacob, D. J., and Yang, X.: Global lifetime of elemental mercury against oxidation by atomic bromine in the free troposphere, Geophys. Res. Lett., 33, L20808, doi:10.1029/2006GL027176, 2006. 
Holmes, C. D., Jacob, D. J., Corbitt, E. S., Mao, J., Yang, X., Talbot, R., and Slemr, F.: Global atmospheric model for mercury including oxidation by bromine atoms, Atmos. Chem. Phys., 10, 12037-12057, doi:10.5194/acp-10-12037-2010, 2010.

Hossaini, R., Chipperfield, M. P., Monge-Sanz, B. M., Richards, N. A. D., Atlas, E., and Blake, D. R.: Bromoform and dibromomethane in the tropics: a 3-D model study of chemistry and transport, Atmos. Chem. Phys., 10, 719-735, doi:10.5194/acp10-719-2010, 2010.

Hossaini, R., Chipperfield, M. P., Feng, W., Breider, T. J., Atlas, E., Montzka, S. A., Miller, B. R., Moore, F., and Elkins, J.: The contribution of natural and anthropogenic very short-lived species to stratospheric bromine, Atmos. Chem. Phys., 12, 371380, doi:10.5194/acp-12-371-2012, 2012.

Hossaini, R., Mantle, H., Chipperfield, M. P., Montzka, S. A., Hamer, P., Ziska, F., Quack, B., Krüger, K., Tegtmeier, S., Atlas, E., Sala, S., Engel, A., Bönisch, H., Keber, T., Oram, D., Mills, G., Ordóñez, C., Saiz-Lopez, A., Warwick, N., Liang, Q., Feng, W., Moore, F., Miller, B. R., Marécal, V., Richards, N. A. D., Dorf, M., and Pfeilsticker, K.: Evaluating global emission inventories of biogenic bromocarbons, Atmos. Chem. Phys., 13, 11819-11838, doi:10.5194/acp-13-11819-2013, 2013.

Iraci, L. T., Michelsen, R. R., Ashbourn, S. F. M., Rammer, T. A., and Golden, D. M.: Uptake of hypobromous acid (HOBr) by aqueous sulfuric acid solutions: low-temperature solubility and reaction, Atmos. Chem. Phys., 5, 1577-1587, doi:10.5194/acp5-1577-2005, 2005.

Kinnison, D. E., Brasseur, G. P., Walters, S., Garcia, R. R., Marsh, D. R., Sassi, F., Harvey, V. L., Randall, C. E., Emmons, L., Lamarque, J. F., Hess, P., Orlando, J. J., Tie, X. X., Randel, W., Pan, L. L., Gettelman, A., Granier, C., Diehl, T., Niemeier, U., and Simmons, A. J.: Sensitivity of chemical tracers to meteorological parameters in the MOZART-3 chemical transport model, J. Geophys. Res., 112, D20302, doi:10.1029/2006JD007879, 2007.

Ko, M. K. W., Sze, N., Scott, C. J. and Weisenstein, D. K.: On the relation between stratospheric chlorine/bromine loading and shortlived tropospheric source gases, J. Geophys. Res., 102, 2550725517, 1997.

Lamarque, J.-F., Emmons, L. K., Hess, P. G., Kinnison, D. E., Tilmes, S., Vitt, F., Heald, C. L., Holland, E. A., Lauritzen, P. H., Neu, J., Orlando, J. J., Rasch, P. J., and Tyndall, G. K.: CAM-chem: description and evaluation of interactive atmospheric chemistry in the Community Earth System Model, Geosci. Model Dev., 5, 369-411, doi:10.5194/gmd-5-369-2012, 2012.

Lary, D. J., Chipperfield, M. P., Toumi, R., and Lenton, T.: Heterogeneous atmospheric bromine chemistry, J. Geophys. Res., 101, 1489-1504, doi:10.1029/95JD02839, 1996.

Leedham, E. C., Hughes, C., Keng, F. S. L., Phang, S.-M., Malin, G., and Sturges, W. T.: Emission of atmospherically significant halocarbons by naturally occurring and farmed tropical macroalgae, Biogeosciences, 10, 3615-3633, doi:10.5194/bg-10-36152013, 2013.

Liang, Q., Stolarski, R. S., Kawa, S. R., Nielsen, J. E., Douglass, A. R., Rodriguez, J. M., Blake, D. R., Atlas, E. L., and Ott, L. E.: Finding the missing stratospheric $\mathrm{Br}_{y}$ : a global modeling study of $\mathrm{CHBr}_{3}$ and $\mathrm{CH}_{2} \mathrm{Br}_{2}$, Atmos. Chem. Phys., 10, 2269-2286, doi:10.5194/acp-10-2269-2010, 2010.
Liang, Q., Atlas, E., Blake, D., Dorf, M., Pfeilsticker, K., and Schauffler, S.: Convective transport of very short lived bromocarbons to the stratosphere, Atmos. Chem. Phys., 14, 5781-5792, doi:10.5194/acp-14-5781-2014, 2014.

Lin, S.-J.: A "vertically lagrangian" finite-volume dynamical core for global models, Mon. Weather Rev., 132, 2293-2307, doi:10.1175/1520-0493(2004)132<2293:AVLFDC>2.0.CO;2, 2004.

Liu, Y., Yvon-Lewis, S. a., Thornton, D. C. O., Butler, J. H., Bianchi, T. S., Campbell, L., Hu, L., and Smith, R. W.: Spatial and temporal distributions of bromoform and dibromomethane in the Atlantic Ocean and their relationship with photosynthetic biomass, J. Geophys. Res. Ocean., 118, 1-16, doi:10.1002/jgrc.20299, 2013.

Mahowald, N. M., Lamarque, J.-F., Tie, X. X., and Wolff, E.: Seasalt aerosol response to climate change: Last Glacial Maximum , preindustrial, and doubled carbon dioxide climates, J. Geophys. Res., 111, 1-11, doi:10.1029/2005JD006459, 2006.

Marcy, T. P., Fahey, D. W., Gao, R. S., Popp, P. J., Richard, E. C., Thompson, T. L., Rosenlof, K. H., Ray, E. A., Salawitch, R. J., Atherton, C. S., Bergmann, D. J., Ridley, B. A., Weinheimer, A. J., Loewenstein, M., Weinstock, E. M., and Mahoney, M. J.: Quantifying stratospheric ozone in the upper troposphere with in situ measurements of $\mathrm{HCl}$., Science, 304, 261265, doi:10.1126/science.1093418, 2004.

Marsh, D. R., Mills, M. J., Kinnison, D. E., Lamarque, J.-F., Calvo, N., and Polvani, L. M.: Climate change from 1850 to 2005 simulated in CESM1(WACCM), J. Clim., 26, 7372-7391, doi:10.1175/JCLI-D-12-00558.1, 2013.

McFiggans, G., Plane, J. M. C., Allan, B. J., Carpenter, L. J., Coe, H., and O'Dowd, C.: A modeling study of iodine chemistry in the marine boundary layer, J. Geophys. Res., 105, 14371-14385, doi:10.1029/1999JD901187, 2000.

Mébarki, Y., Catoire, V., Huret, N., Berthet, G., Robert, C., and Poulet, G.: More evidence for very short-lived substance contribution to stratospheric chlorine inferred from $\mathrm{HCl}$ balloon-borne in situ measurements in the tropics, Atmos. Chem. Phys., 10, 397-409, doi:10.5194/acp-10-397-2010, 2010.

Meinshausen, M., Smith, S. J., Calvin, K., Daniel, J. S., Kainuma, M. L. T., Lamarque, J.-F., Matsumoto, K., Montzka, S. A., Raper, S. C. B., Riahi, K., Thomson, A., Velders, G. J. M., and Vuuren, D. P. P.: The RCP greenhouse gas concentrations and their extensions from 1765 to 2300, Clim. Change, 109, 213-241, doi:10.1007/s10584-011-0156-z, 2011.

Montzka, S. A., Reimann, S., Engel, A., Krüger, K., O`Doherty, S., and Sturges, W. T.: Ozone-Depleting Substances (ODSs) and Related Chemicals, Chapter 1 in Scientific Assessment of Ozone Depletion: 2010, Global Ozone Research and Monitoring Project-Report No. 52, Geneva, Switzerland., 1.1-1.108 pp., 2011.

Murphy, D. M., Fahey, D. W., Proffitt, M. H., Liu, S. C., Chan, K. R., Eubank, C. S., Kawa, S. R., and Kelly, K. K.: Reactive nitrogen and its correlation with ozone in the lower stratosphere and upper troposphere, J. Geophys. Res., 98, 8751-8773, doi:10.1029/92JD00681, 1993.

Neale, R. B., Richter, J., Park, S., Lauritzen, P. H., Vavrus, S. J., Rasch, P. J., and Zhang, M.: The Mean Climate of the Community Atmosphere Model (CAM4) in Forced SST and Fully Cou- 
pled Experiments, J. Clim., 26, 5150-5168, doi:10.1175/JCLID-12-00236.1, 2013.

Neu, J. L. and Prather, M. J.: Toward a more physical representation of precipitation scavenging in global chemistry models: cloud overlap and ice physics and their impact on tropospheric ozone, Atmos. Chem. Phys., 12, 3289-3310, doi:10.5194/acp-12-32892012, 2012.

Ordóñez, C., Lamarque, J.-F., Tilmes, S., Kinnison, D. E., Atlas, E. L., Blake, D. R., Sousa Santos, G., Brasseur, G., and Saiz-Lopez, A.: Bromine and iodine chemistry in a global chemistry-climate model: description and evaluation of very short-lived oceanic sources, Atmos. Chem. Phys., 12, 1423-1447, doi:10.5194/acp12-1423-2012, 2012.

Parrella, J. P., Jacob, D. J., Liang, Q., Zhang, Y., Mickley, L. J., Miller, B., Evans, M. J., Yang, X., Pyle, J. A., Theys, N., and Van Roozendael, M.: Tropospheric bromine chemistry: implications for present and pre-industrial ozone and mercury, Atmos. Chem. Phys., 12, 6723-6740, doi:10.5194/acp-12-6723-2012, 2012.

Pfeilsticker, K., Sturges, W. T., Bosch, H., Camy-Peyret, C., Chipperfield, M. P., Engel, A., Fitzenberger, R., Muller, M., Payan, S., and Sinnhuber, B.-M.: Lower stratospheric organic and inorganic bromine budget for the arctic winter 1998/99, Geophys. Res. Lett., 27, 3305-3308, 2000.

Pyle, J. A., Ashfold, M. J., Harris, N. R. P., Robinson, A. D., Warwick, N. J., Carver, G. D., Gostlow, B., O’Brien, L. M., Manning, A. J., Phang, S. M., Yong, S. E., Leong, K. P., Ung, E. H., and Ong, S.: Bromoform in the tropical boundary layer of the Maritime Continent during OP3, Atmos. Chem. Phys., 11, 529-542, doi:10.5194/acp-11-529-2011, 2011.

Quack, B. and Wallace, D. W. R.: Air-sea flux of bromoform: Controls, rates, and implications, Global Biogeochem. Cy., 17, 1023, doi:10.1029/2002GB001890, 2003.

Randel, W. J. and Jensen, E. J.: Physical processes in the tropical tropopause layer and their roles in a changing climate, Nat. Geosci., 6, 169-176, doi:10.1038/ngeo1733, 2013.

Rayner, N. A.: Global analyses of sea surface temperature, sea ice, and night marine air temperature since the late nineteenth century, J. Geophys. Res., 108, 4407, doi:10.1029/2002JD002670, 2003.

Rex, M., Wohltmann, I., Ridder, T., Lehmann, R., Rosenlof, K., Wennberg, P., Weisenstein, D., Notholt, J., Krüger, K., Mohr, V., and Tegtmeier, S.: A tropical West Pacific $\mathrm{OH}$ minimum and implications for stratospheric composition, Atmos. Chem. Phys., 14, 4827-4841, doi:10.5194/acp-14-4827-2014, 2014.

Saiz-Lopez, A. and von Glasow, R.: Reactive halogen chemistry in the troposphere, Chem. Soc. Rev., 41, 6448-6472, doi:10.1039/c2cs35208g, 2012.

Saiz-Lopez, A., Lamarque, J.-F., Kinnison, D. E., Tilmes, S., Ordóõez, C., Orlando, J. J., Conley, A. J., Plane, J. M. C., Mahajan, A. S., Sousa Santos, G., Atlas, E. L., Blake, D. R., Sander, S. P., Schauffler, S., Thompson, A. M., and Brasseur, G.: Estimating the climate significance of halogen-driven ozone loss in the tropical marine troposphere, Atmos. Chem. Phys., 12, 3939-3949, doi:10.5194/acp-12-3939-2012, 2012.

Sala, S., Bönisch, H., Keber, T., Oram, D. E., Mills, G., and Engel, A.: Deriving an atmospheric budget of total organic bromine using airborne in situ measurements from the western Pacific area during SHIVA, Atmos. Chem. Phys., 14, 6903-6923, doi:10.5194/acp-14-6903-2014, 2014.
Salawitch, R. J.: Atmospheric chemistry: biogenic bromine, Nature, 439, 275-277, doi:10.1038/439275a, 2006.

Salawitch, R. J., Weisenstein, D. K., Kovalenko, L. J., Sioris, C. E., Wennberg, P. O., Chance, K., Ko, M. K. W., and McLinden, C. A.: Sensitivity of ozone to bromine in the lower stratosphere, Geophys. Res. Lett., 32, L05811, doi:10.1029/2004GL021504, 2005.

Sander, R.: Compilation of Henry's Law Constants for Inorganic and Organic Species of Potential Importance in Environmental Chemistry (v3), available at: http://www.henrys-law.org/ (last access 28 May 2014), 1999.

Sander, R. and Crutzen, P. J.: Model study indicating halogen activation and ozone destruction in polluted air masses transported to the sea, J. Geophys. Res., 101, 9121-9138, doi:10.1029/95JD03793, 1996.

Sander, S. P., Friedl, R. R., Barker, J. R., Golden, D. M., Kurylo, M. J., Sciences, G. E., Wine, P. H., Abbatt, J. P. D., Burkholder, J. B., Kolb, C. E., Moortgat, G. K., Huie, R. E., and Orkin, V. L.: Chemical Kinetics and Photochemical Data for Use in Atmospheric Studies, Evaluation No. 17, JPL_NASA, 10-6(17), Jet Propulsion Laboratory, Pasadena, CA, 2011.

Sinnhuber, B.-M. and Folkins, I.: Estimating the contribution of bromoform to stratospheric bromine and its relation to dehydration in the tropical tropopause layer, Atmos. Chem. Phys., 6, 4755-4761, doi:10.5194/acp-6-4755-2006, 2006.

Sinnhuber, B.-M., Sheode, N., Sinnhuber, M., Chipperfield, M. P., and Feng, W.: The contribution of anthropogenic bromine emissions to past stratospheric ozone trends: a modelling study, Atmos. Chem. Phys., 9, 2863-2871, doi:10.5194/acp-9-2863-2009, 2009.

Sommariva, R. and von Glasow, R.: Multiphase halogen chemistry in the tropical Atlantic Ocean., Environ. Sci. Technol., 46, 10429-10437, doi:10.1021/es300209f, 2012.

Thompson, A. M., Witte, J., Oltmans, S., Schmidlin, F., Logan, J., Fujiwara, M., Kirchhoff, V., Posny, F., Coetzee, G., Hoegger, B., Kawakami, S., Ogawa, T., Fortuin, J. P. F., and Kelder, H.: Southern Hemisphere Additional Ozonesondes (SHADOZ) 1998-2000 tropical ozone climatology 2. Tropospheric variability and the zonal wave-one, J. Geophys. Res., 108, 8241, doi:10.1029/2002JD002241, 2003.

Tilmes, S., Kinnison, D. E., Garcia, R. R., Salawitch, R., Canty, T., Lee-Taylor, J., Madronich, S., and Chance, K.: Impact of very short-lived halogens on stratospheric ozone abundance and UV radiation in a geo-engineered atmosphere, Atmos. Chem. Phys., 12, 10945-10955, doi:10.5194/acp-12-10945-2012, 2012.

Warwick, N. J., Pyle, J. A., Carver, G. D., Yang, X., Savage, N. H., O'Connor, F. M., and Cox, R. A.: Global modeling of biogenic bromocarbons, J. Geophys. Res., 111, D24305, doi:10.1029/2006JD007264, 2006.

Wegner, T., Kinnison, D. E., Garcia, R. R., and Solomon, S.: Simulation of polar stratospheric clouds in the specified dynamics version of the whole atmosphere community climate model, J. Geophys. Res. Atmos., 118, 4991-5002, doi:10.1002/jgrd.50415, 2013.

Williams, J. E., Van Zadelhoff, G.-J., and Scheele, M. P.: The effect of updating scavenging and conversion rates on cloud droplets and ice particles in the global chemistry transport model, KNMI Tech. Rep., TR-308, Koninklijk Nederlands Meteorologisch Instituut, De Bilt, the Netherlands, 45 pp., 2009. 
Wisher, A., Oram, D. E., Laube, J. C., Mills, G. P., van Velthoven, P., Zahn, A., and Brenninkmeijer, C. A. M.: Very short-lived bromomethanes measured by the CARIBIC observatory over the North Atlantic, Africa and Southeast Asia during 2009-2013, Atmos. Chem. Phys., 14, 3557-3570, doi:10.5194/acp-14-35572014, 2014.

Yang, X., Cox, R. A., Warwick, N. J., Pyle, J. A., Carver, G. D., O'Connor, F. M., and Savage, N. H.: Tropospheric bromine chemistry and its impacts on ozone: A model study, J. Geophys. Res., 110, D23311, doi:10.1029/2005JD006244, 2005.
Ziska, F., Quack, B., Abrahamsson, K., Archer, S. D., Atlas, E., Bell, T., Butler, J. H., Carpenter, L. J., Jones, C. E., Harris, N. R. P., Hepach, H., Heumann, K. G., Hughes, C., Kuss, J., Krüger, K., Liss, P., Moore, R. M., Orlikowska, A., Raimund, S., Reeves, C. E., Reifenhäuser, W., Robinson, A. D., Schall, C., Tanhua, T., Tegtmeier, S., Turner, S., Wang, L., Wallace, D., Williams, J., Yamamoto, H., Yvon-Lewis, S., and Yokouchi, Y.: Global sea-toair flux climatology for bromoform, dibromomethane and methyl iodide, Atmos. Chem. Phys., 13, 8915-8934, doi:10.5194/acp13-8915-2013, 2013. 